\author{
DUQUESNE LIGHT COMPANY \\ SHIPPINGPORT ATOMIC POWER STATION
}

\title{
TEST RESULTS
}

DLCs 3330101

1B HEAT EXCHANGER LEAK TEST

CORE I SEED 1 


\section{DISCLAIMER}

This report was prepared as an account of work sponsored by an agency of the United States Government. Neither the United States Government nor any agency Thereof, nor any of their employees, makes any warranty, express or implied, or assumes any legal liability or responsibility for the accuracy, completeness, or usefulness of any information, apparatus, product, or process disclosed, or represents that its use would not infringe privately owned rights. Reference herein to any specific commercial product, process, or service by trade name, trademark, manufacturer, or otherwise does not necessarily constitute or imply its endorsement, recommendation, or favoring by the United States Government or any agency thereof. The views and opinions of authors expressed herein do not necessarily state or reflect those of the United States Government or any agency thereof. 


\section{DISCLAIMER}

Portions of this document may be illegible in electronic image products. Images are produced from the best available original document. 
TEST RESULTS

DLCS. 3330101

1B HEAT . EXCHANGER LEAK TEST

CORE I - SEED . 1

\section{Purpose}

Tests were performed to determine which, tubes of the $1 \mathrm{~B}$ heat exchanger were leaking primary coolant water into the secondary water system. Different testing methods were used to locate the leak source in the tubes and to determine, if possible, the cause of tuhe defects.

\section{Conclusions}

The air pressurization test determined the heat exchanger leakage and leak rate of individual tubes. On the basis of this method 9 tubes were plugged prior to returning the $1 B$ boiler to service, after the refueling operation. This brought the total number of plugged tubes in the 1B heat exchanger to 26 .

The leak location detector probe is a promising method of locating defects along the length of a tube, however, due to sludge deposition after shutdown, only one crack was located in four tubes. Results of the probolog test, dye penetrant test and ultrasonic test were inconclusive in determining the :lpcation of leaks. No definite reason for tube leakage co uld be determined from the results of this test.

\section{Description of Test Equipment and Test Procedure}

The following are descriptions of tests performed:

A. The air pressure test has been the basic physical method by which heat exchanger tubes have been tested for leakage of radioactive primary system water into the secondary system. With, the hydraulic stop valves of the loop closed and water drained from both sides of the heat exchanger, air pressure of 75 psig was applied to the secondary (she11) side. Each tube was then filled with water on the primary side and observation made at both the inlet and outlet end of the tube to detect emission of air bubbles as leakage evidence. Leaky tubes were marked by inserting a solid rubber stopper in the heat exchanger outlet and inserting a rubber stopper with a small hole in the tube at the heat exchanger inlet.

In order to determine the leak rate for defective tubes, a plastic hose was inserted into the rubber stopper of the heat exchanger inlet. The other end of the hose was placed under the open end of a glass graduate which had been filled with, water and inverted in a bucket of water * Air entering the defective tube from the secondary side ( 75 psig) was led into the graduate where a volume of water displacement could be measured over a period of time. 
B. The probolog test was done with insertion into the tube of an eddy-current probe where magnetic flux is used to indicate failures. This probolog equipment is specialized apparatus. which was supplied by Westinghouse Electric Corporation, Bettis P1ant, and operated by Westinghouse personnel during testing。

C. The leak location detector probe was designed to locate the position of a crack along the length of a heat exchanger tube. Prior to testing the solid rubber stopper in the outlet end of the tube was replaced by a one hole stopper with a short piece of plastic tubing, the end of which was placed in a bottle of water. The probe, as shown in Figure 1, was inserted into a dry tube after the secondary side had been pressurized to 75 psig. When a crack in the tube was located between the two rubber seals of the probe, pressurized air entering this space escaped through the tubing and was detected by bubbles issuing from the end under water.

During testing, the probe was advanced into a leaking tube in 5 inch increments with a waiting time of at least 20 seconds between increments, depending on the leak rate of the tube. Bubbling in the bottles at both ends of the tube was used to determine when all cracks in the tube had been located. If the crack was not located within 26 feet of the inlet tube sheet, the probe was removed and the test procedure repeated from the outlet end of the tube.

D. The hnregage test was used to determine the inside diameter of selected tubes at the hemt exchanger inlet. The boregage equipment, furnished by Westinghouse:Electric Corporation, Bettis Plant, consisted of a split measuring head bearing on the tube inside diameter and producing an axial deflection of tapered extension rods. Rod movement actuated a dial indicator from which inside diameter readings were taken. During testing various length extension rods were used to permit gaging of selected tubes up to 11 13/16" from the tube sheet.

E. Ultrasonic testing of selected tubes was accomplished with special equipment supplied by Westinghouse Electric Corporation, Bettis Plant. A special 5 megacycle search unit, Figure 2, was coupled with an Imerscope from which readings were taken at various distances up to $91 / 2$ inches frpm the face of the inlet tube sheet. Westinghouse personnel operated the Immerscope and recorded data accoding to interpretation of the observed signals.

F. Dye penetrant inspection was used to check the inlet end of selected heat exchanger tubes. Tubes were cleaned with cloth patches, blown dry with air and dried with an electric heater inserted into the tube. Dye penetrant was swabbed on the inside surfaces of the tubes up to 15 " from the end and left for 15 minutes. The surface was then swabbed to remove excess. penetrant and a 15" section of rubber tubing closed at the end, was inserted into the tube. The tubing was inflated with $20-30$ psig air and held in place for 5 minutes. Air pressure was then removed and the rubber tubing removed for examination of dye penetrant transferred from defects in the metal to the surface of the tubing. 
TEST : RESULTS DLCS 3330101

1B. HEAT EXCHANGER LEAK TEST

CORE I I SEED 1

\section{Results}

DLCS 3330101, 1B Heat Exchanger Leak Tests, was performed at various periods during 1959 and up to March 28, 1960. When this performance began, there were 11,804 service hours on the 1B Heat Exchanger.

Intial plugging of tubes in the 1B heat exchanger was done, during February 1958 on the basis of air pressurization and probolog tests which indicated defects in 17 tubes. These tubes are shown in Figure 3. Examination of tubes removed from the boller indicated that cracks were due to a form of caustic stress corrosion. For additional information on the defected tubes, see $B$ and W. Co. Report No. 7089. After installation of two additional risers, the heat exchanger was returned to service with a change in boiler water chemistry to prevent free alkalinity.

During April, 1959, lodine activity was detected in the secondary water of the $1 \mathrm{~B}$ heat exchanger and this activity continued during plant operation until octtober 1959, whpn the loop was removed from service prior to core I,. Seed 2 refueling. Probolog testing of 140 tubes was performed and results indicated defects in 114 tubes. Further investigation showed the presence of ferromagnetic sludge on the sides of the tubes. This sludge rendered results of the probolog tests inconclusive and data were not taken by Duquesne Light Company. Data accumulated during this test may be found in Westinghouse letter WAPD - PWR -2160 of March 18, 1960 .

Alr pressurization tests were conducted to determine leaking tubes and leak rates. Figure 4 notes the tubes for which leakage was detected per Table.I: Rechecks of the suspected leaking tubes in Table $\mathbb{I}$ determined that tube 20 row 12, tube 21 row 20 and tube 22 row 24 did not leak. The leak rates for the remaining tubes were determined to be as follows:

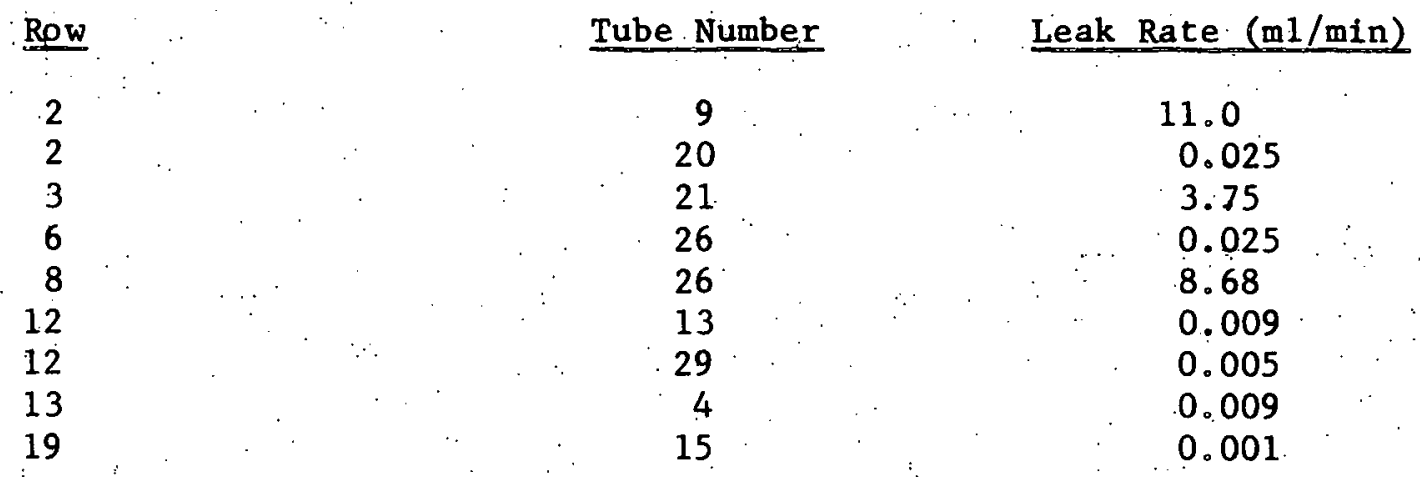

It will be noted that three tubes provided most of the leakage, the other 6 having a very low leak rate.

In order to determine the cause of tube leakage it was decided to locate the defect position in the above tubes having measureable leak rates. Refueling 
operationg delayed grinding of the tube lipg, to perwit entry of the leak location detector probe, for two months. Table II presents the test data and hows that only one tube indicated leakage. Blowing tube 9, row 2 with air on the primary side still did not produce leakage when the secondary side was pressurized. These results Indicated that the defects were so small that they were closed by boller sludge during the dry layup of 2 months.

Consideration was given to puling tubes through the tube she for It was necessary, however, to first determine if the tubes were expanded beyond the 8" tube sheet thickness. A boregage instrwment was used on selected tubes as noted in Figure 5. The daca in Table III showed that tube rolling extended a minimum of $83 / 4 "$ from the face of the tube sheet for all tubas checked. It is logical to assume this fabrication method was used for all tuber and that special techniques would be required to collapse the expanded turs action before pulling a tube through the sheet.

The dye penetrant athod was utilized to deterine if cracks whin the tube sheet area could be detected. Twelve tubes, show in Figure, and the dye penetrant pattern on the rubber tublng are indicated in Figures 7-16. Results of these data cin be mumarized as follows:

\begin{tabular}{|c|c|c|c|c|}
\hline ube & Row & $\begin{array}{l}\text { Location } \\
\text { (Inches from tube sheet) }\end{array}$ & $\begin{array}{l}\text { Length } \\
\text { (inckes) }\end{array}$ & Direction \\
\hline$* 9$ & 2 & $12 ; 13$ & $1 / 16 ; 1 / 8$ & Long1 tudinal \\
\hline$* 26$ & 8 & $31 / 4 ; 51 / 2 ; 6,1 / 4$ & $1 / 4 ;-; 1 / 2$ & Long1 tuding 1 \\
\hline$* 29$ & 12 & $13 / 4 ; 103 / 4$ & $1 / 16 ; 1 / 16$ & Circumferential \\
\hline 13 & 12 & $101 / 2$ & $3 / 16$ & Wagona 1 \\
\hline .14 & .21 & $111 / 4$ & $3 / 16$ & Lapol \\
\hline$* 15$ & 19 & $12.5 / 16$ & $1 / 16$ & Mragona 1 \\
\hline 23 & 19 & $121 / 4$ & $\cdots$ & Dlagomal \\
\hline 10 & 30 & $41 / 4 ; 115 / 16$ & $\infty$ & Longi tudinal; \\
\hline 14 & 30 & 9 & $5 / 16$ & Longi tudion 1 \\
\hline
\end{tabular}

Leaking tubes per alr pressurization test

Indications on the rubber tubing were a thin crack type frow 1/6" $1 / 16^{\prime \prime} 10 \mathrm{mg}$ laying in varlous directions. The fact that defects are indicated that did not previously show leakage casts doubt on the interpretation of the tubing dye penetrant patterns. . Since none of the defects in leaking tubes were accurately located, there was no standard by which this penetrant technique could be judged. Repetitive tests on various tubes were inconclusive as to whether a defect Indication would be repeated. From these results no conclusions could be drawn as to whether cracks were present in the tubes.

U1trasonic tests were also made to determine if tube defects could located by this method. The tubes tested are noted on Figure 17 and dat tated in 


\section{B HEAT EXCHANGER LEAK TEST, CORE I I SEED 1}

Table IV. This ultrasonic equipment was of specialized design and required inter。 pretation by personnel experienced in its application. These data were taken and recorded by Westinghouse personnel. Communications received by: Duquesne Light Company from Westinghouse have indicated that results of this ultrasonic testing were not conclusive in determining the location of leaks in those heat exchanger tubes tested.

On March 3 and 4, 1960 a film badge survey was made of the tube sheet and hemispherical head area of the $1 \mathrm{~B}$. Steam Generator to determine the radiation levels. These radiation levels were taken at two and six inches from the tube sheet at the inlet side of the steam generator. The locations of the film packets were: (1) Row 7, Tube 22, (2) Row 26, Tube 3, and (3) Row 21, Tube 16. The tube locations correspond to $70^{\prime} \mathrm{clock}, 2 \mathrm{o}^{\prime} \mathrm{clock}$, and the center respectively with the tubes numo bered from right to left and the rows from bottom to top. The film packets in.. special holders were exposed at the above positions with the following types of shielding: (1) no shielding (2) $1 / 6$ in. thick plastic (3) $5 / 16$ in. thick plastic (lucite) (4) 20 mil thick cadmium. . The shielding covered both sides of the film. The exposed film was developed by. Westinghouse Electric Corporation, Bettis.Plant, and the results are shown in Table.V.

In comparing the various methods used for detecting tube leakage and locating these leaks, satisfactory results were obtained only from the air pressurization test and the leak location detector probe test. However, it was shown that leak detection is impaired by boiler layup periods which permit residue to plug existing cracks. Although a layup period prevented demonstration of the full capabilities of the leak location detector test, this method should prove to be adequate. No definite reason for the tube leakage could be postulated since the location and nature of the cracks were not determined. Probulug tests were affected to such a great extent by tube surface conditions that results were inconclusive. Likewise, location of tube defects by dye penetrant and ultrasonic testing require refinement of technique to provide reliable results。

On the basis of the air pressurization test 9 tubes were plugged in the i. heat exchanger. Figure 3 represents the state of this heat exchanger as it was returned to service with Core $I_{9}$ : Seed 2 .

When the boiler was returned to power, it had a higher. leak rate than when it was removed from service for the refueling period. The leak rate was determined by the following equation.

$$
1=\frac{A_{b}}{A_{c}} \frac{(b+\lambda) v}{\left[1-e^{-(b+\lambda) \cdot t}\right]}
$$

1 = leak rate, $\mathrm{ml} / \mathrm{min}$

$A_{b}=$ boiler water $I^{133}$ activity, dpm/ml

$A_{c}=$ Reactor Coolant I I33 activity $\mathrm{dpm} / \mathrm{m} 1$

$$
\begin{aligned}
& \lambda=\text { decay constant, I } 133.5 .54 \times 10^{-4} .1 / \mathrm{min} \\
& \hat{V}=\text { boiler volume, } 5.9 \times 10^{6} \mathrm{~m} 1
\end{aligned}
$$

$\mathrm{b}=1$ oss due to sampling, $7.6 \times 10^{-5} .1 / \mathrm{min}$

$t=$ : time, mịnutes

The leak rates obtained from this equation are listed in Table.VI. As shown by the data the leak rate is higher after refueling when the nine tubes were plugged than before refueling. This rise in the leak rate points to two possibilities: (1). A new leak could have occurred on the start-up of the plant after refueling (2) The limitation of any of the present means of determining leaking tubes. From Table VI it can be seen that the leak rate is tending to decrease as the operating time increases on the heat exchanger. No conclusion can be obtained at this time from this trend. 
DUQUESNE LIGHT COMPANY

POWER STATIONS DEPARTMENT

SHIPPINGPORT ATOMIC POHER STATION
1B HEAT EXCHANGER LEAR TEST DLCS 3330101

CORE I SEED 1

FIGURE 1

Leak Location Detector Probe

1/2" O.D. Metal Washer

$11 / 16^{\prime \prime}$

O.D. Soft Rubber

Seal

Metal Washer

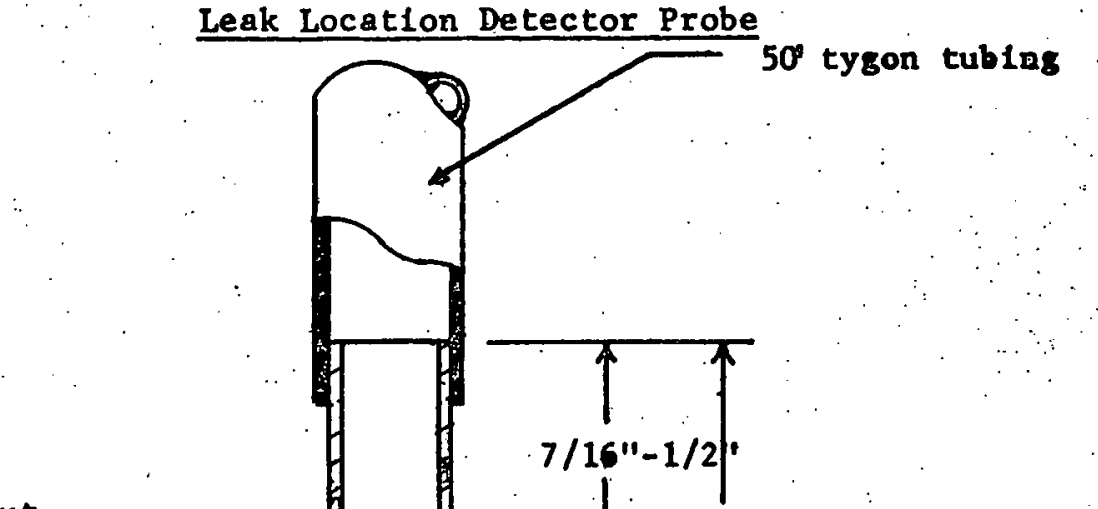

Nut

Tubing to be slotted through one wall over $50 \%$ of length

between wäshers

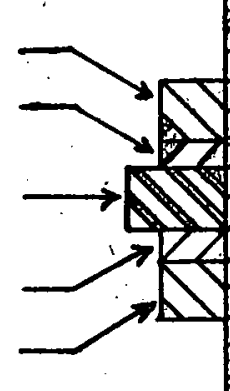

- Threaded

as necessary

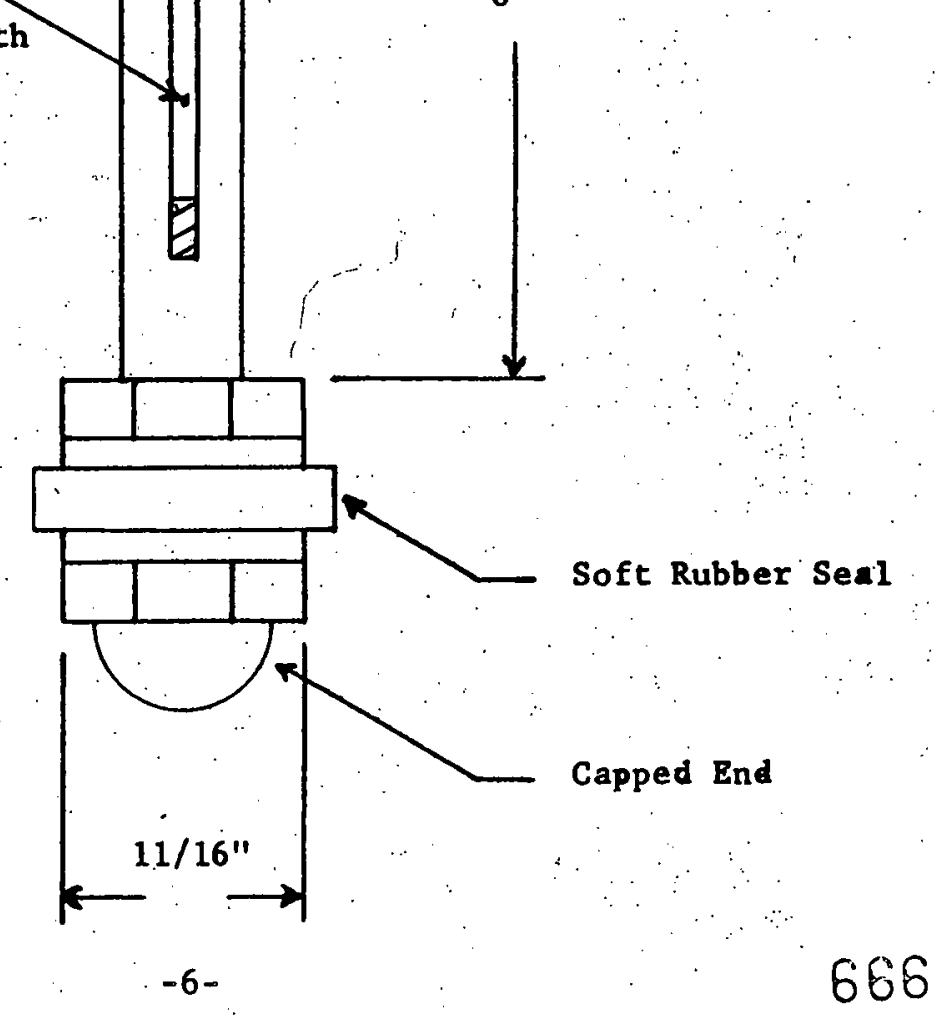


DUQUESNE LIGHT COMPANY

PCYTR STATIONS DEPARTMENT

SHIPPINGPORT ATOMIC POWER STATION
1B HEAI EXCHANGER IEAR TEST DLCS 3330101

CORE I SEED 1

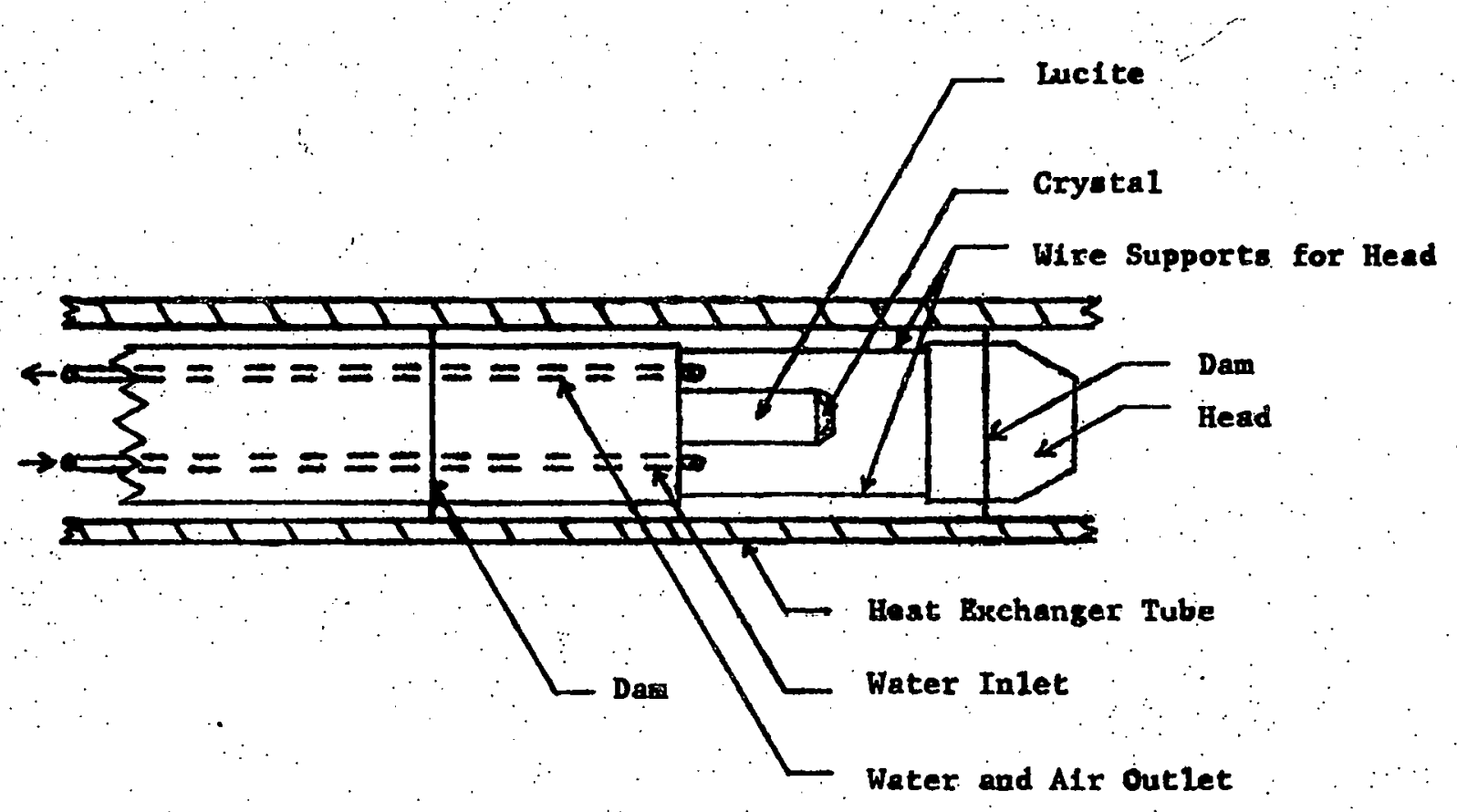

FIGURE 2

OItrasonfe Search Unit

$-7-$ 
DUQUESNE LIGHT COMPANY

POWER STATION DEPARTMENI

YIPPINGPORT ATOMIC POWER STATION
1. HEAT BXCHANGER LEAK TIST

DLCS 3330101

CORE I SEED 1

FIGURE 3

18 Heat Exchanger Plugged Tubes

$00 \times(\times) \times 1818080000$ 
DUQUESNE LIGHT COMPANY

POWER STATIONS DEPARTMENT

SHIPPINGPORT ATOMIC POWER STATION
13 HEAT EXCHANGER LEAR TEST

DLCS 3330101

CORE I SEED 1

FIGURE 4

Alr Pressurization Test

000000000000

$1000 \times 1 \times$

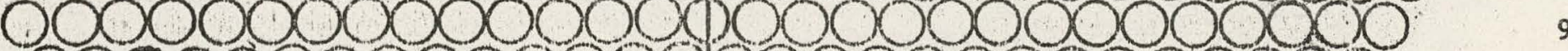

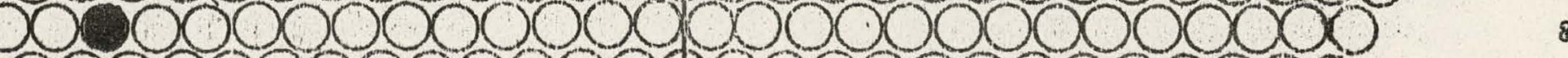

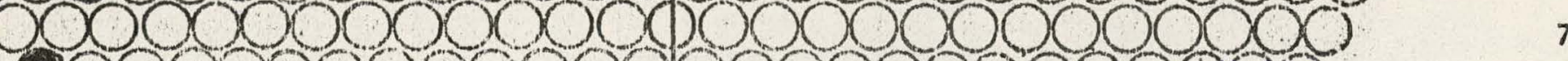

$-2 \times(\times) \times(\times) \times(x) \times(x)$

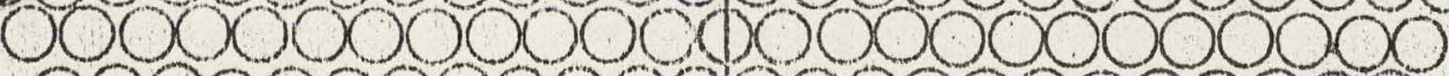

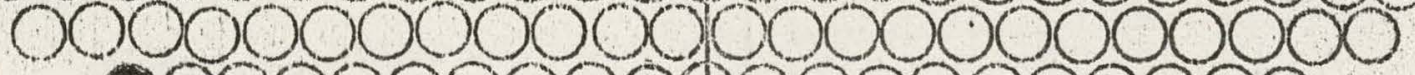

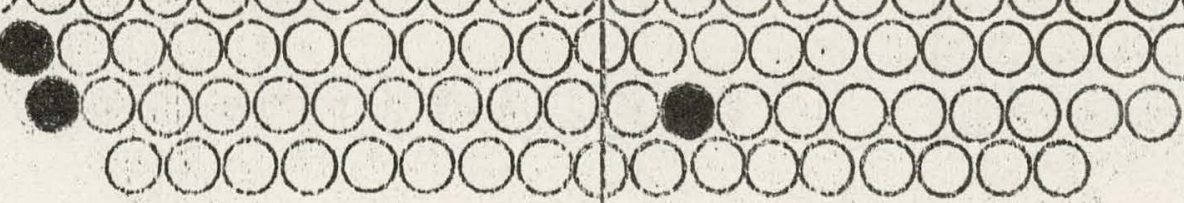


DUQUESNE LIGHT COMPANY

POWER STATIONS DEPARTMENT

SHIPPINGPORT ATOMIC POWER STATION
1B HEAT EXCHANGER LEAK TEST

DLCS 3330101

CORE I SEED 1

\section{FIGURE 5}

\section{Boregage Test Tubes}

\section{0}

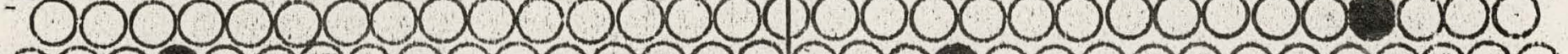

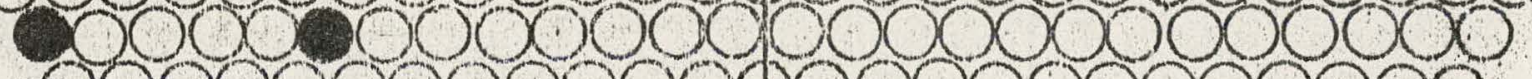


DUQUESNE LIGHT COMPANY

POWER STATION DEPARTMENT

SHIPPINGPORT ATOMIC POWER STATION
1B HEAT EXCHANGER LEAK TEST

DLCS 3339101

CORE I SEED 1

FIGURE 6

Tubes Tested with Dye Penetrant

000000000000

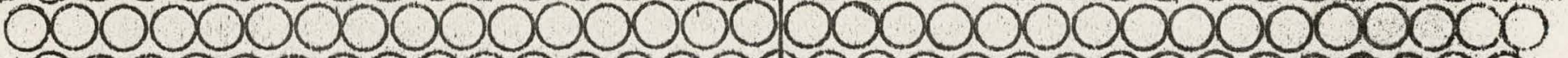

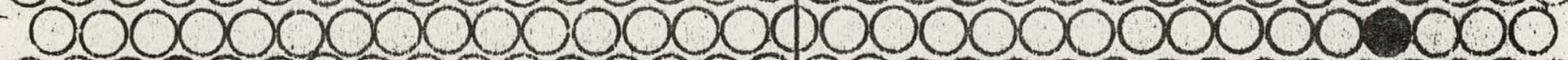

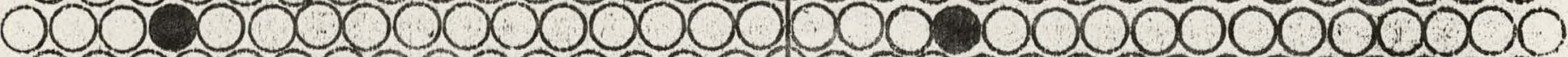

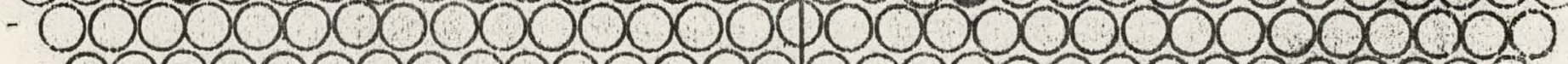

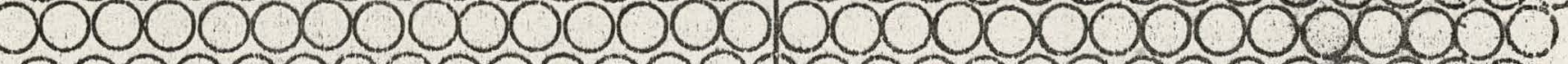

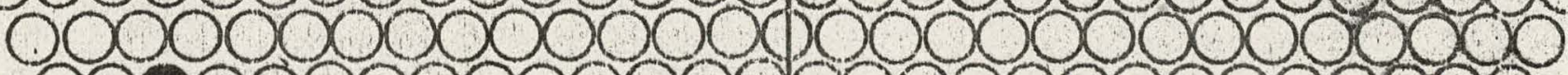

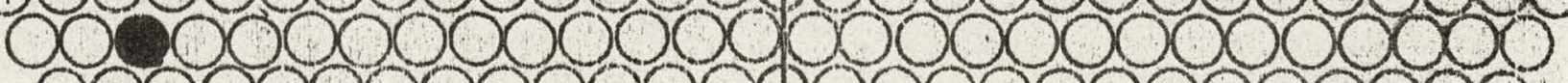
$0 \times 0 \times(x)(0000000$ - $x(x)(x)(x) \times 0 \times(x)$

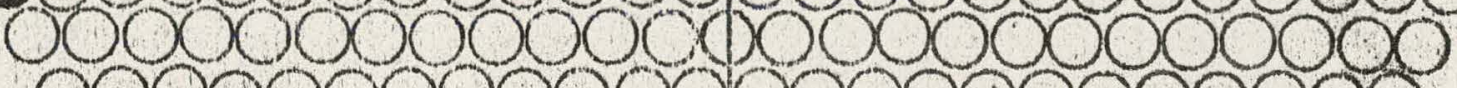
$0000 \times(3) \times(9) \times 0 \times 0$

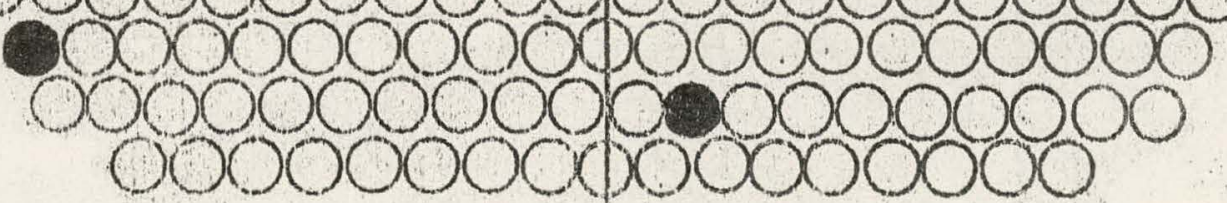


DUQUUESNE LIGHT COMPANY

POWER STATIONS DEPARTMENT

SHIPPINGPORT ATOMIC POWER STATION
1B HEAT EXCHANGER LEAK TEST

DLCS 3330101

CORE I SEED 1

FIGURE 7

Dye Penetrant Indications of Tube 9, Row 2

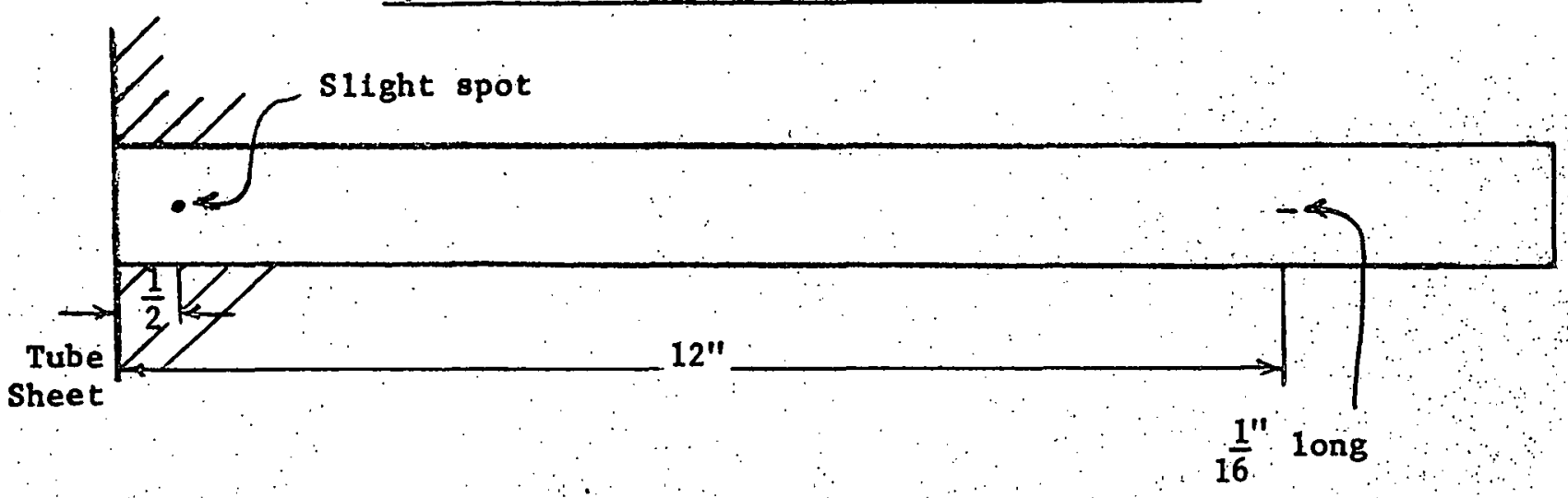

Checked 3-20-60

, sh:

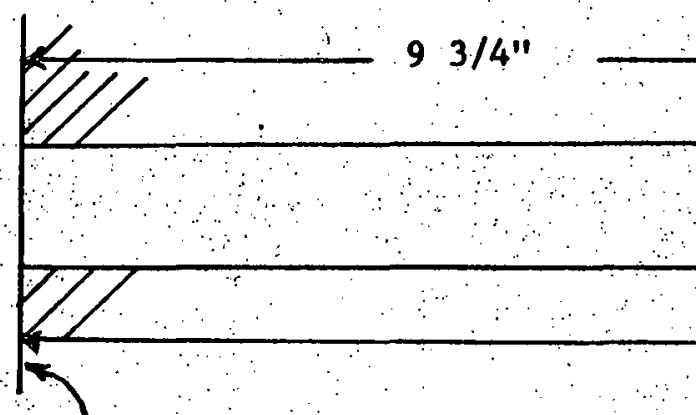

Tube Sheet
Round spot

$1 / 8$ " Diameter

At 11 o'clock

Checked $3-28-60$ 
DUQUESNE LIGHT COMPANY POWER STATIONS DEPARTMENT

SHIPPINGPORT ATOMIC POWER STATION
1B HEAT EXCHANGER LEAK TEST DLCS 3330101

CORE I SEED 1

FIGURE :

Tube 21 , Row 3

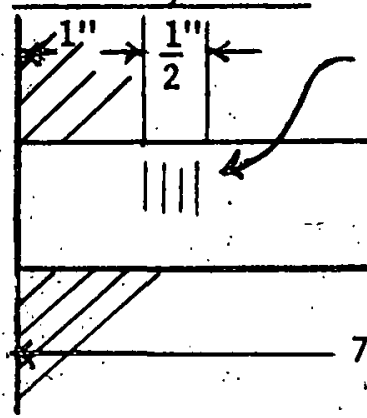

Dye Penetrant Indications

Small Circumferential Marks at 12 o'clock

$7^{1 / 2 "}$

Pit Indicated at $40^{\prime}$ clock

Checked 3-23-60

Tube 26 , Row 6

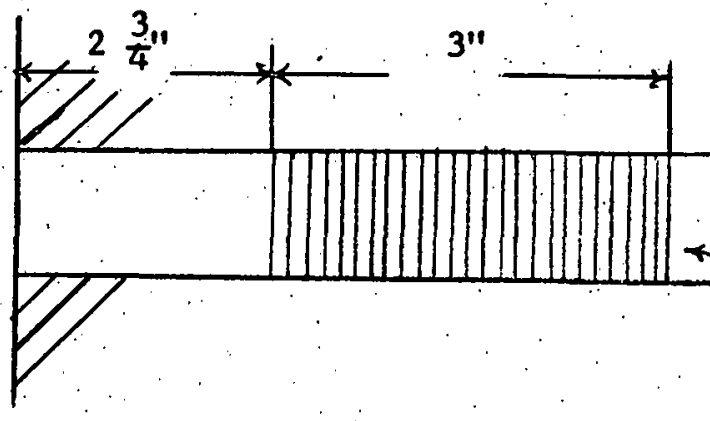

Approximately 26 circumferential IInes around the tube. The line are nearly evenly spaced.

Row 6 Tube 26

Date checked 3-23-60

No Indications 3-28-60

Recheck 
DUQUESNE LIGHT COMPANY OWIA STATIONS DEPARTMENT

RIPPINGPORT ATOMIC FOWKR STATION
1B HEAT BXCEAHOZR LEAK TEST DLCS 3330101

CORE I SEED 1

\section{PIGURE 9}

Dye Penetrant Indicatinns of Tube 26, Row 8

.

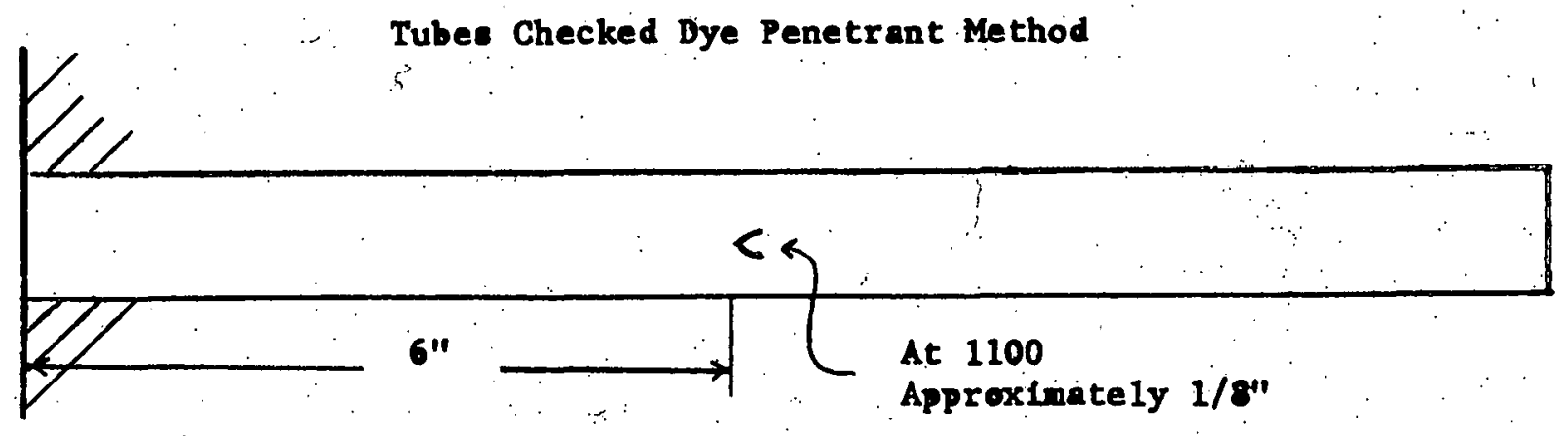

Checked 3-23-60

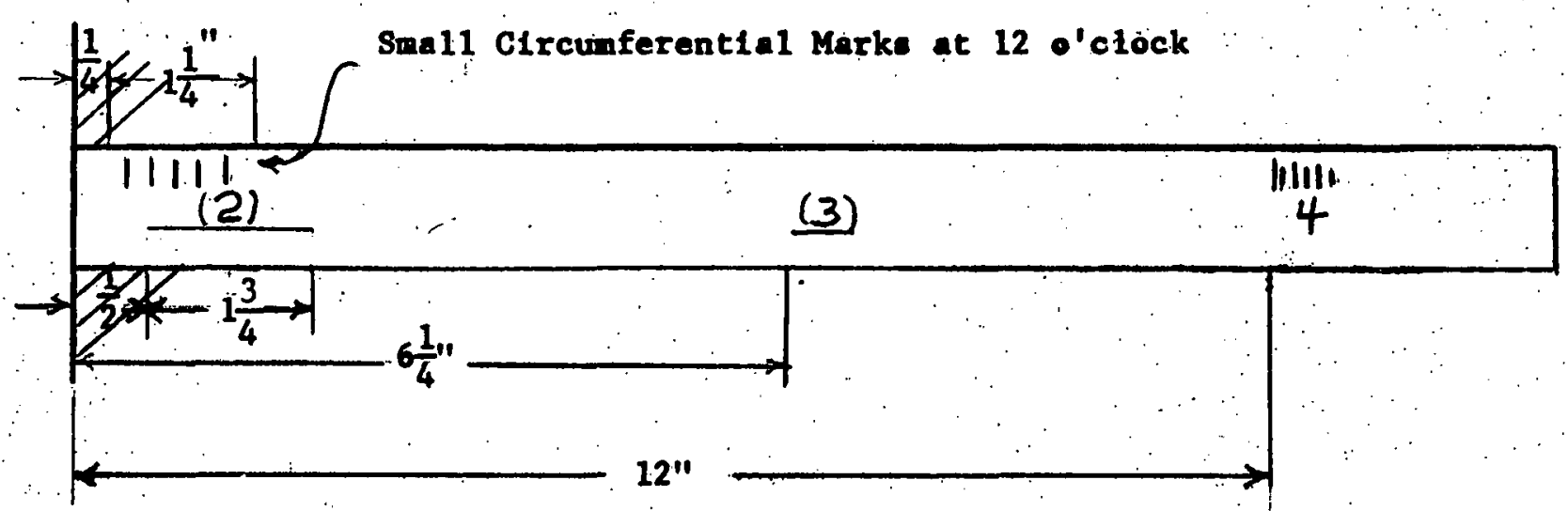

(2) Herizontel Mark at 1200

If he $3 / 4^{\prime \prime}$ becones deeper for the naxt $1^{\prime \prime}$

(3) Deep grove at 12 'clock, 1/2" ling

(4) Fine clrcumferential marks at 12 o'clock

Checked 3-2.3-60

-14 . 
DUQURSNE LIGHT COKPANY POWLR STATIONS DEPARTMENTI

AIPPINGPORT ATOMIC POWL STATION

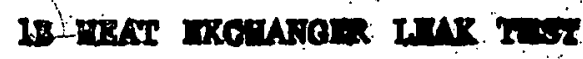
DLC8 3330101

CONB I SRED 1

FIGURE 10

Dye Penetrant Indicatione of Tube 26, Row 8

Tube Checked Dye Penetrant Method

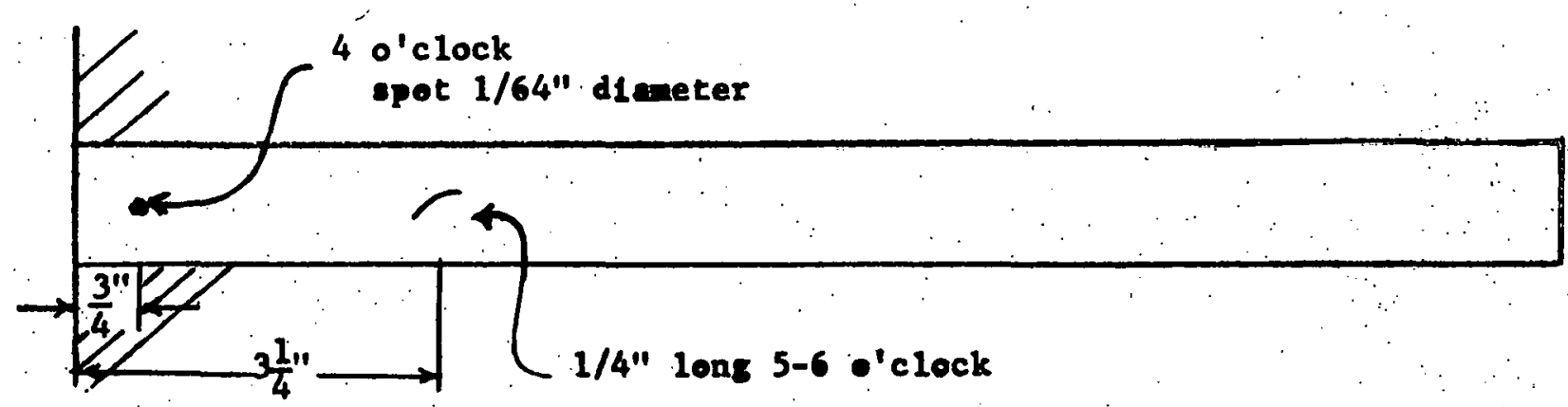

Checked 3-28-60

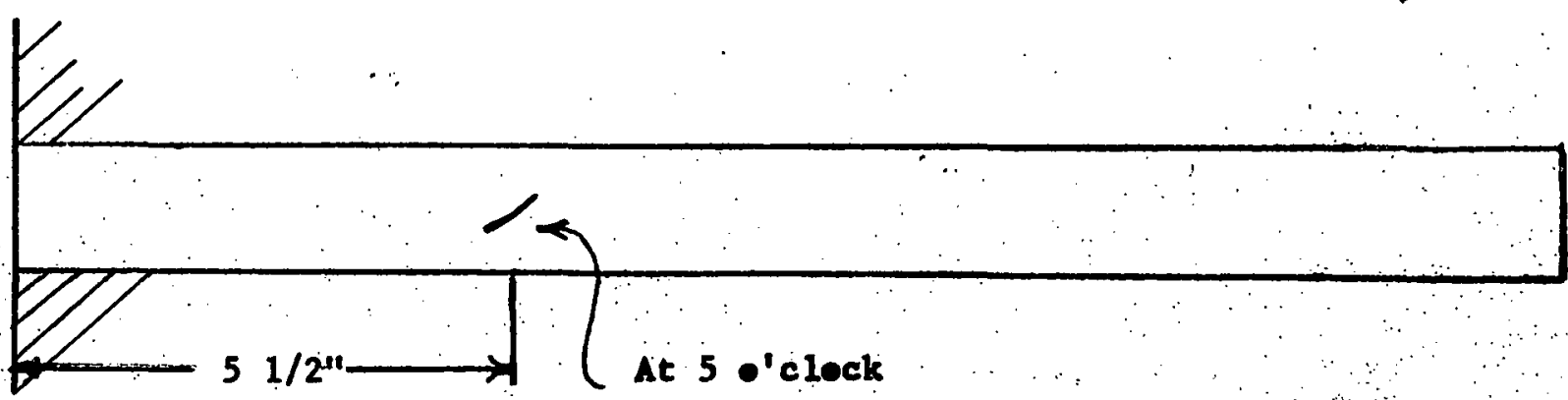

Checked 3-28-60

A thfird teot ande 3-28-60 showed no indications. 
DUQUESNE IIGHT COMPANY

PNWER STATIONS DEPARTMENT

IPPINGPORT ATOMIC POWER STATION

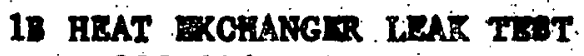
DLCS 3330101

CORE I SEED 1

FIGURE 11

Dye Penetrant Indlcatione of Tube $29 ;$ Row 12

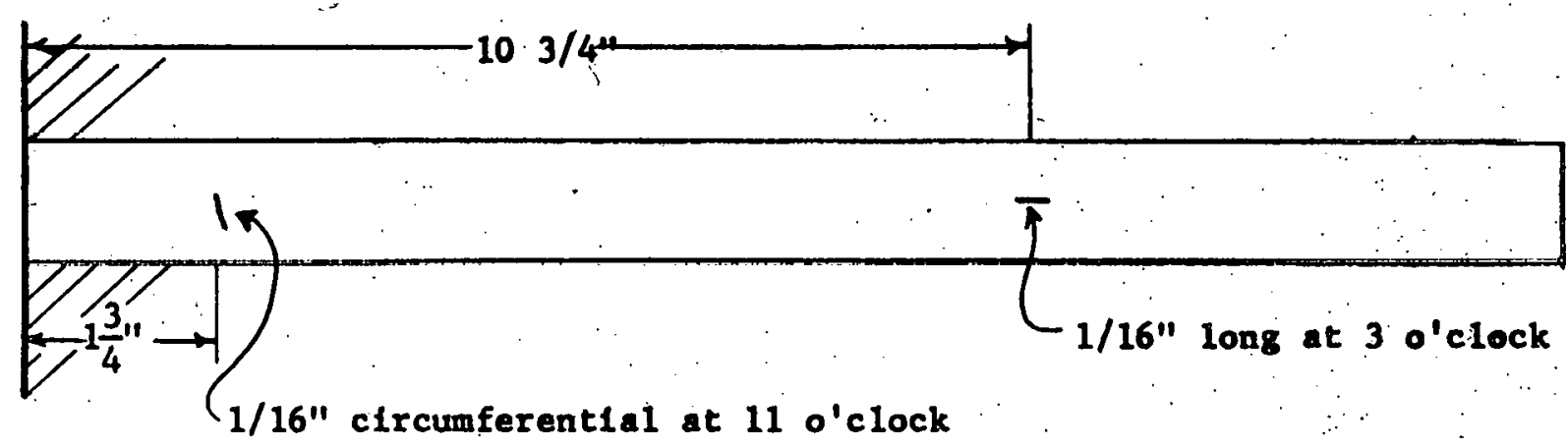

Checked 3-28-60

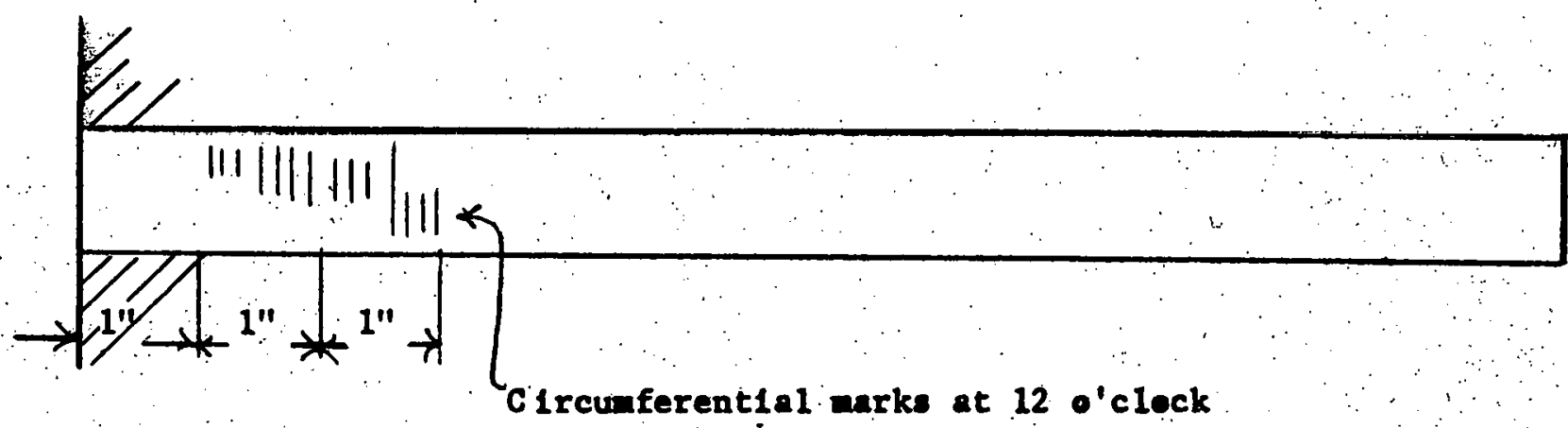

Checked 3-23-60 
DUQUESNE IIGAC COMANY JWER STATIONS DEFARTMENT

-IIPPINGPORT ATOMIC POWER STATION is HEAT EXOWAWAR: LEAK TEBT DLCS 3330101

CORE I SEE 1

\section{FIGURE 12}

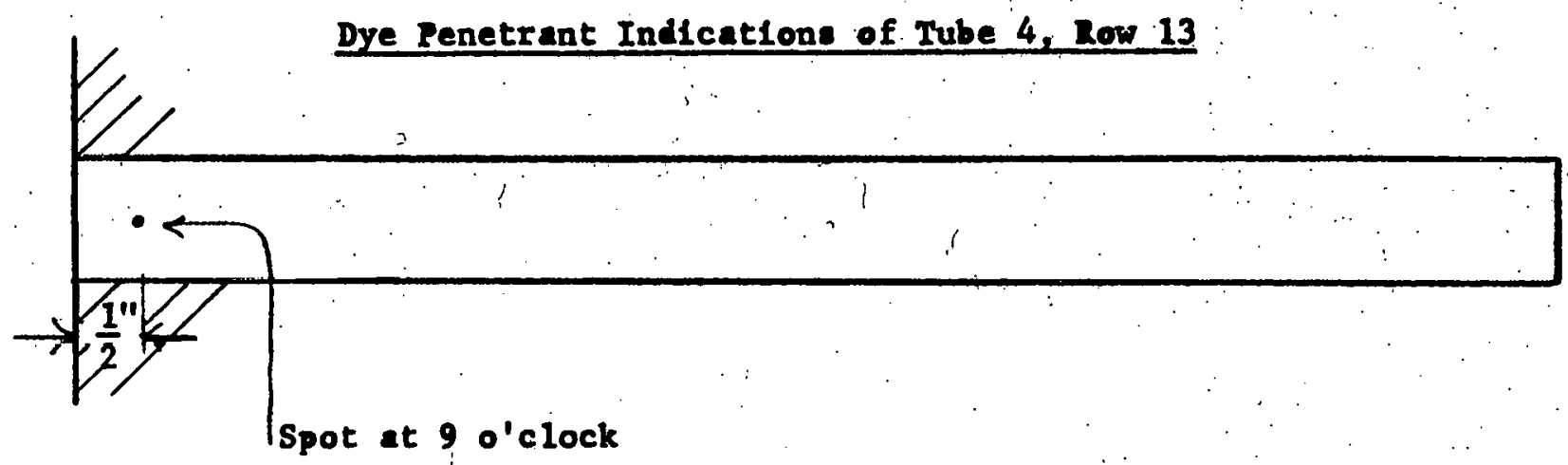

Chéeked 3-20-60

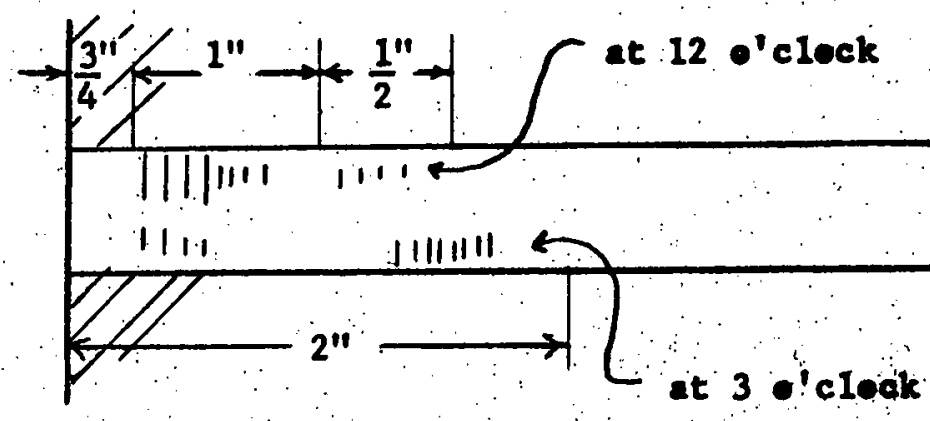

A11 lines were inali approxinate if 1/g" Ions

Checked 3-28-60 
WuQuESNE IYear convint

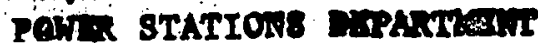

IPPINGPORT ATOMIC POWL STATION

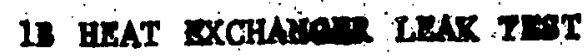
DLCS 3330101

CORE I SESD 1

FIGURE 13

Dye Penetrant. Indicatione

Tube 13, Row 12

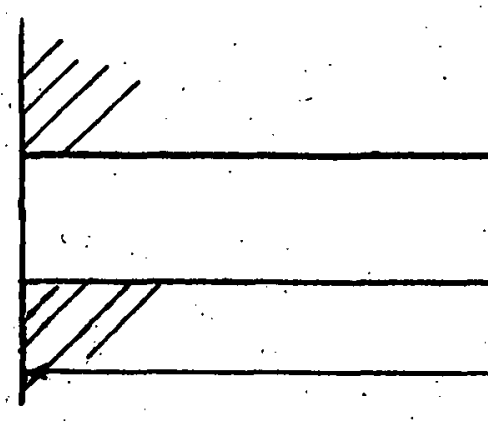

3/16" long at 7 e'cleck

Checked 3-20-60

Tube 14, Row 21

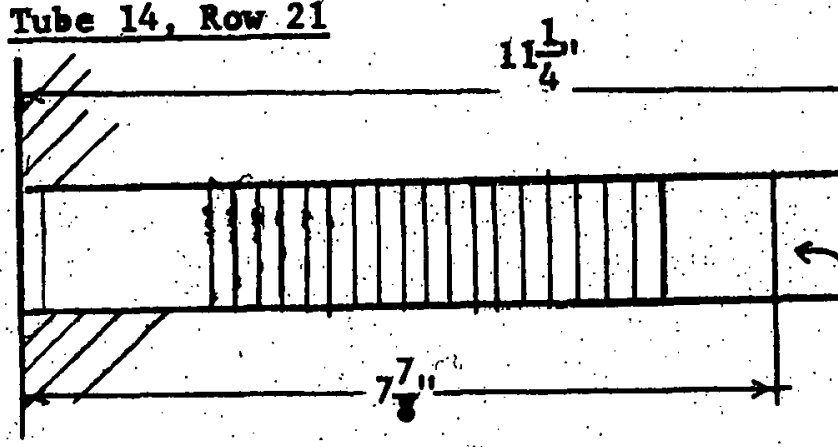

Many Cl reimferentid

Marks : evenily ipaced

A11 marks not thown

Checked 3-28-60 


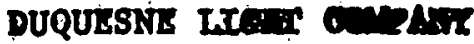

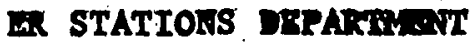

PPINOFORT ATOMIC POW STATION
1. DAT ROHANGK FSAK TEST

DIas 3330101

CORE I SET 1

FLOUR 14

Dye Penetrant Indications of Tube 15, Row 19

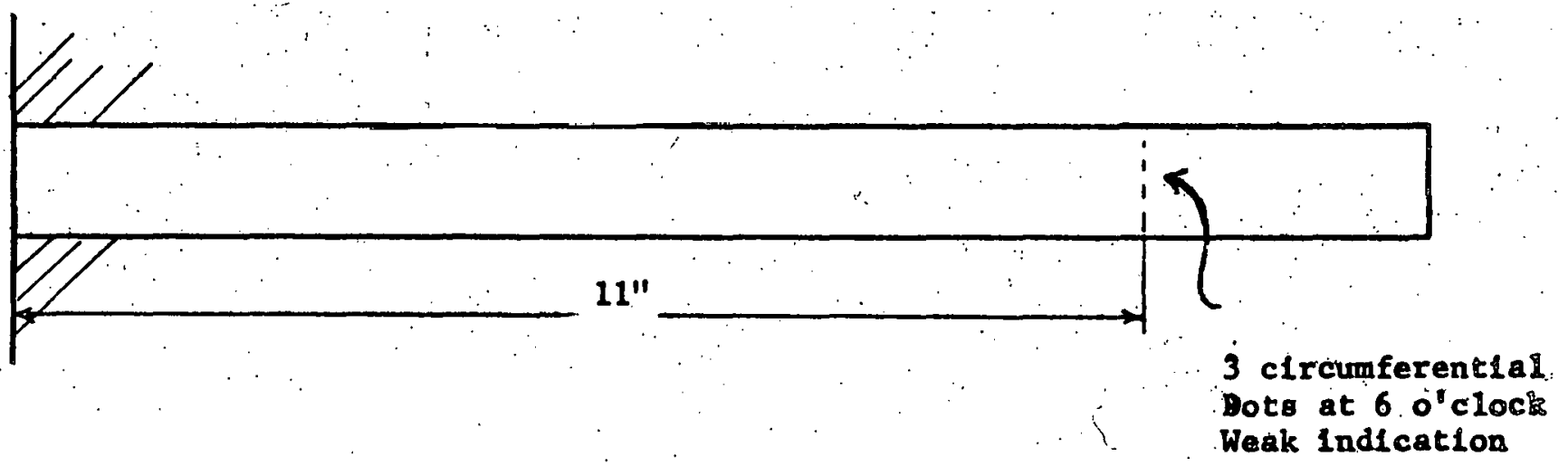

Checked 3-20-60

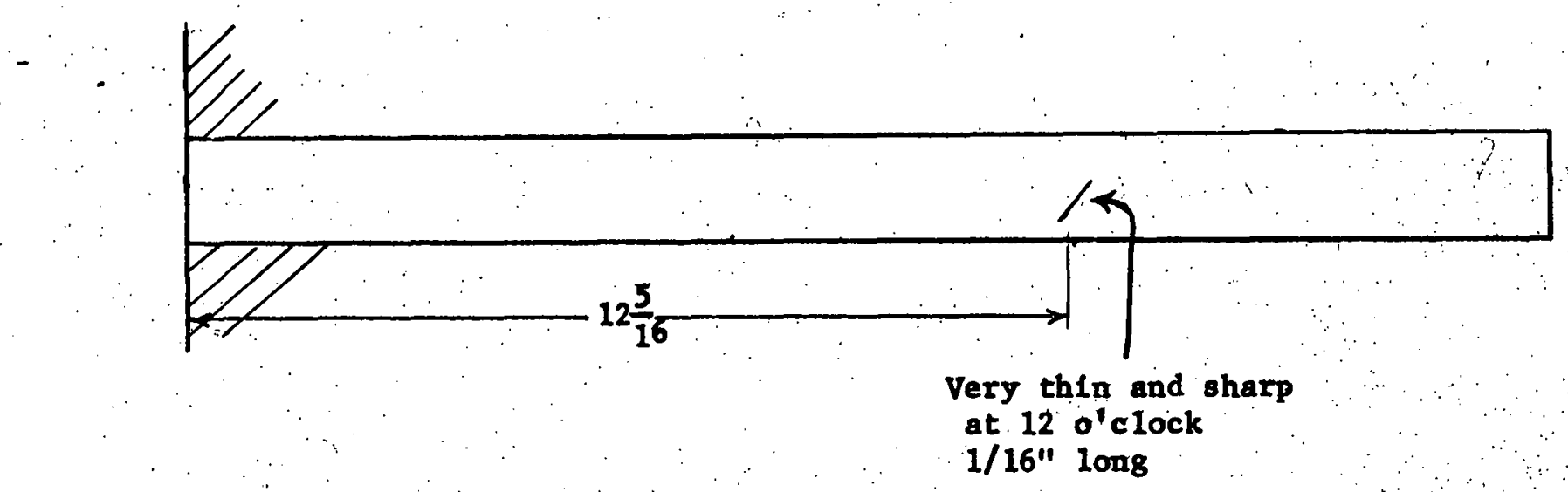

Checked 3-28-60

$668 \quad 20$

$-19-$ 
DUQUESNE LIGHT COMANI POWER STATIONS DLPARTMENT

- PPINGPORT ATOMIC POWTS STATION
18 HRAT RECTANGL LTK TET DLCS 3330101

Cant I SEE 1

FIGURE 15

Dye Penetrant Indlcatlons

Tube 15, Row 19
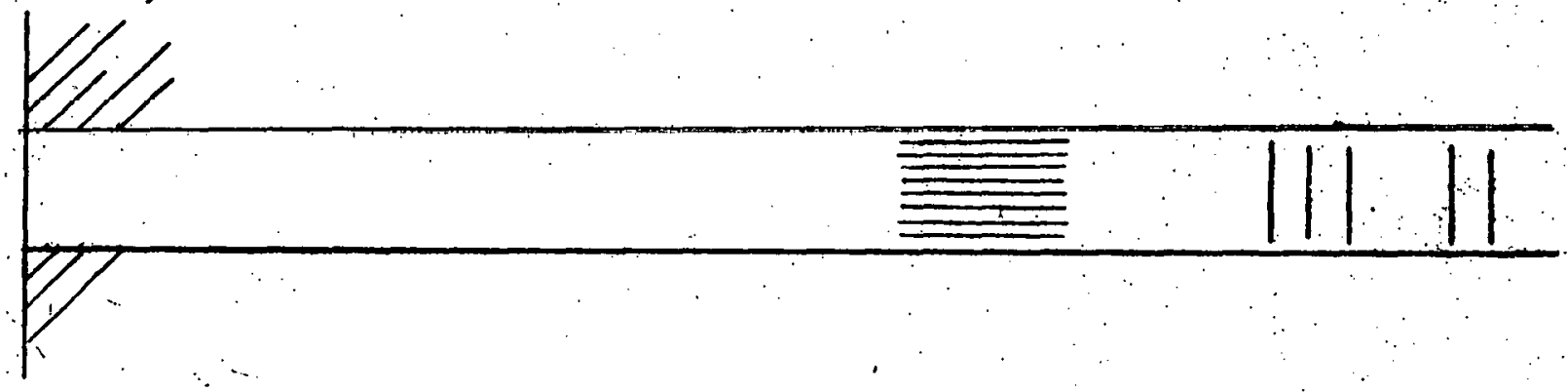

Checked 3-28-60

Tube 23, Row 19

$6 / 4 \frac{4}{4} \rightarrow-\frac{1}{2}+\quad$ ReII Narke

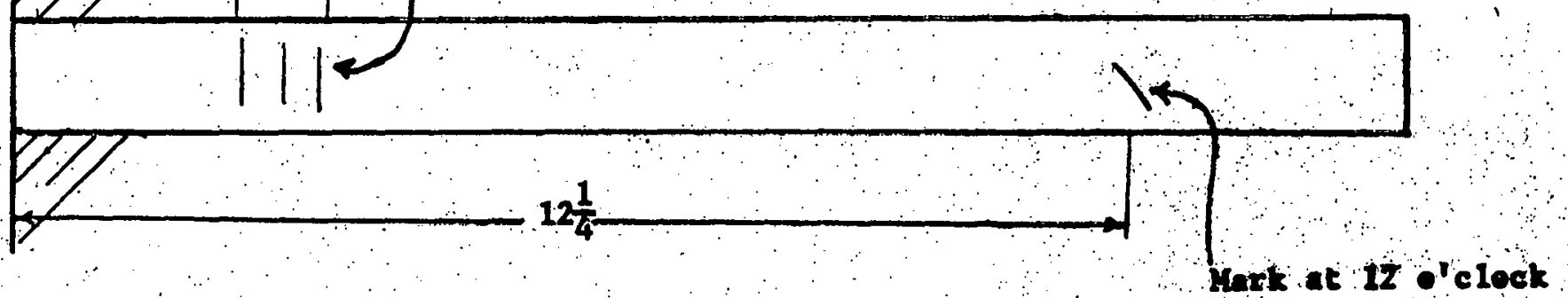

Checked 3-28-60

680

21 
DUQQUESNE LIGHT COMPANY

POWER STATIONS DEPARTM TIT

IPPINGPORT ATOMIC POWLR STATIOA
18 HEAT ERCNANOE LAK TEST

DLCS 3330101

CONE I SEED 1

FIGURE 16

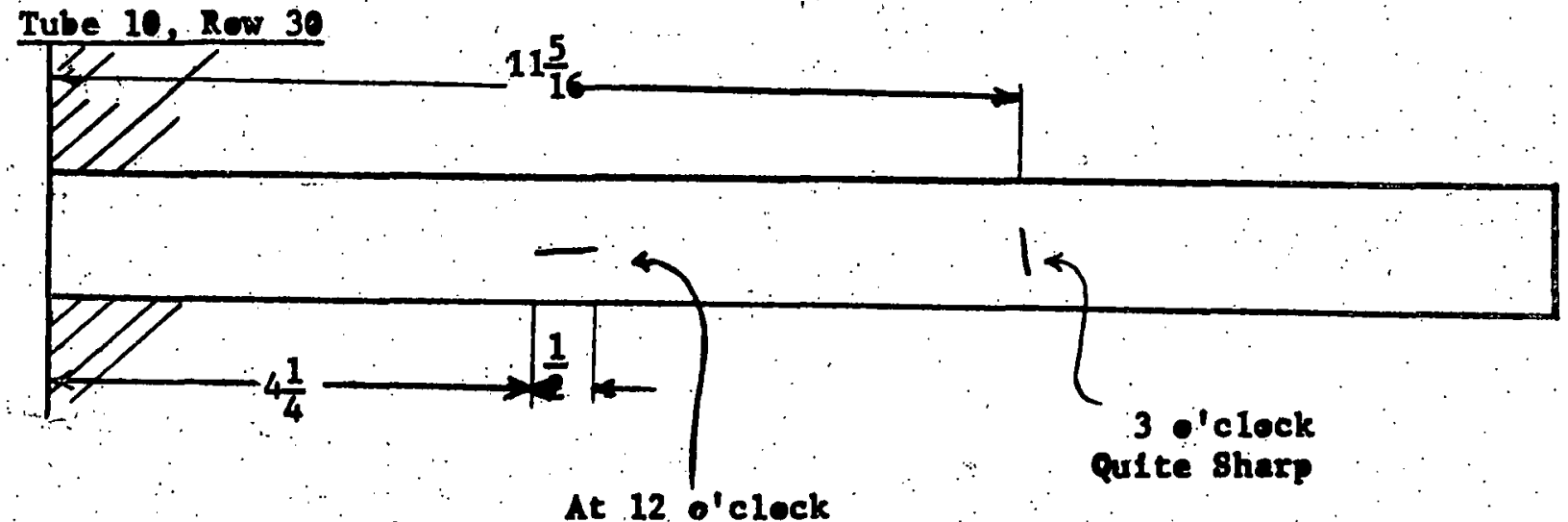

\section{Dye Penetrent Indlentions}

Tube 10, Raw 30

At 12 o'clock

Checked 3-20-60

Tybe 14, Row 30

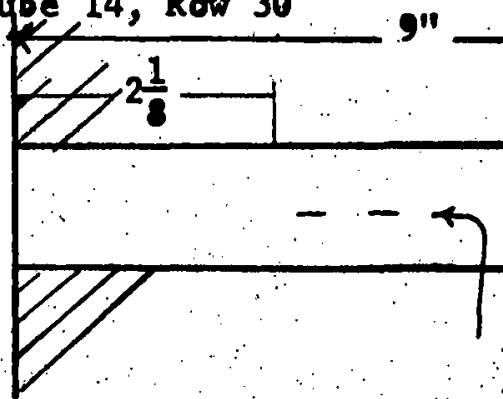

At 5 - 'cleck

Approxifiately 1/8" Ions

Checked 3-28-60

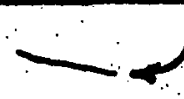




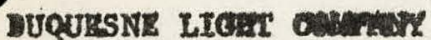

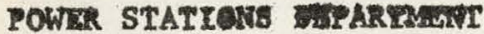

STIPPINGPORT ATOMIC FOWER STATION

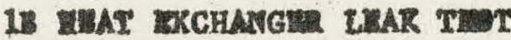

DLC8 333 101.

CORE I STER 1

FIGURE 17

Trhes Thated Br U1trasenic Mathod

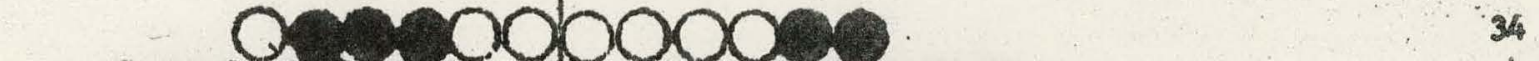

OONOOOOOOOW 33

$0000+32$

$0 \times 100,1.9000$

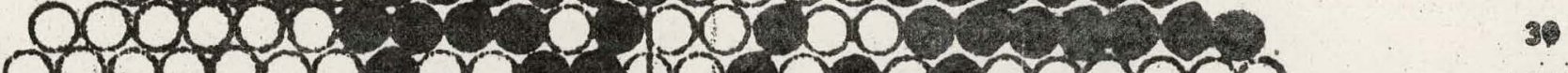

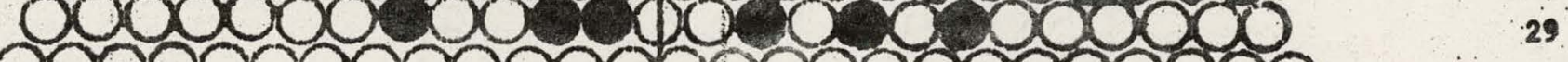

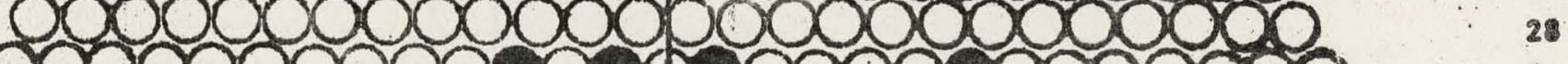

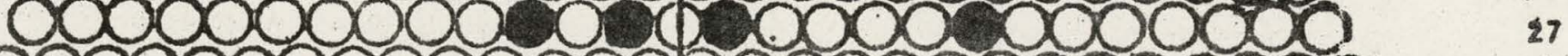

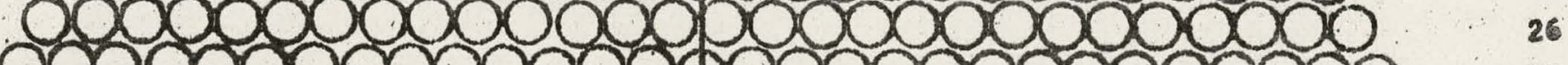

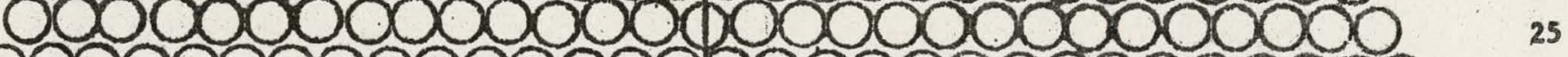

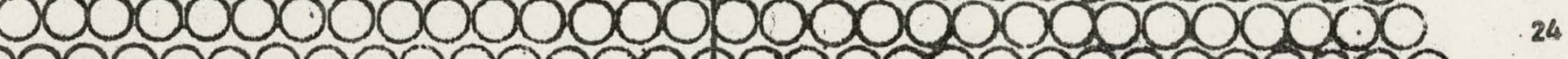

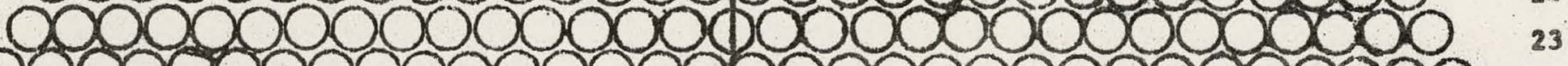

00000000000000000000000000000

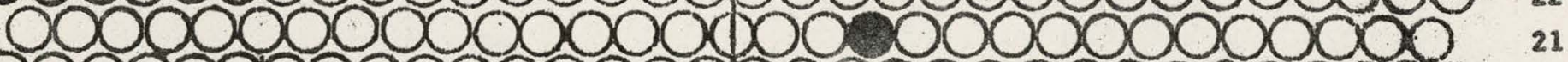

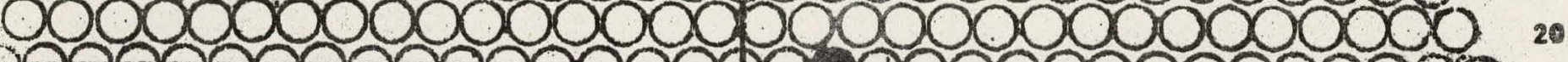

0000000000000000

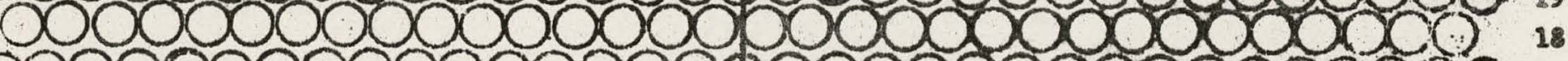

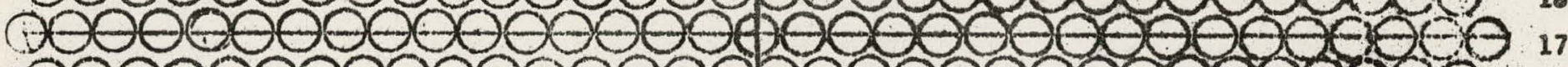

$0000000000000000000000000000 \times 1 \times \times 0$ i6

$0000000000000000000000000000 \times x \times 15$

$00000000000000000000000000000 x{ }_{14}$

$0000000 \times 0 \times 0000000000000.13$

0000000000000000000012

000000000000000011

10

$000000000 \times 0 \times 000000000 \times 0$.

00000000000000000000000

$00000000 \times 000000000000$

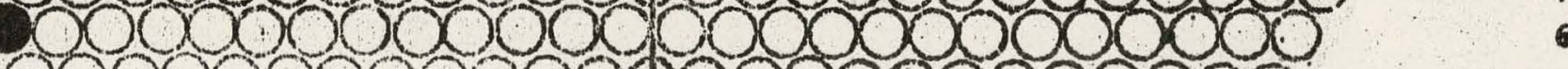

$.00000000 \times 000000000000.5$

$00000000000 \times 00000000000 \quad 4$

$0 \times 0 \times 00000000000000000$

$000000000000 \times 000000$

$00000000 \times 0 \times 0000$

(Inlet View)

-22- Tubes numbered right to left 
DUQUUESNE LIGHT COLPART

POWER STATIONS DEPARTWILNT

SHIPPINGPORT ATOMIC POWER :STATION

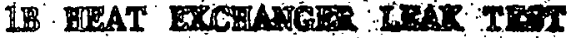

DLCS 3330101

CORE I S 1

\section{TADIE I I}

\section{Tuber Indicating Ieakage During Ali Presourlzation Togt}

Observation:-

Ros

2

3

4

5

6

7

8

9

10

11

12

13

14

15

16

17

18

19

20

21

22

23

24

25

26

27

28.

29 .

30

31

32

33

34
Tube Inlet

Tube No. and Iogkage

No Ieakers

$9: 20$

110

w1/10

\section{min: 11ght}

leakage lind-

L

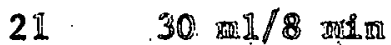

No Iealsers

No ligateris

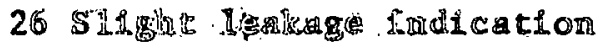

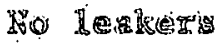

2627.5 mIl/3 and 10 sec.

No learkes

No leatrer

No leakers

13:29 \$1 ight leaklug 1nd leation

4 SIIght leatolog lndleation

No leakerg

No leakers

No leakers

No. leakers

No. leskers

15 silght leakage indication

21 Fossible leakage

No leakers

No leakers

No leakers

No leakers

No leakers

No . leakers

No leakers

No leakers

No leakers

No leakers

No leakers

No. leakers

No leakers

No leakers
Tube Outiet

Tube No. and Irakage

No leakerg

No I I

No 1eakm

No leakers

No Ieraters

No leakers.

No. Ieares

No learers

No Ieakers

- No leakers

20 Possible leakage

No 10aker

No leakers

No leakers

No leakers

Ho Leasers

Wo 1eakons

No leakms

No leakers

No leakers

No leakers

No leakers

22 Possib le leakage

No leakers

No leakers

No leakers

No leakers

No leakers

No Ieakers

No leakers

No leakers

No leakers

No leakers

Secondary Pressure 75 prig

See Figure 4 
DUQUESNE LIGET COMPANY

POWER STATIONS DEPARTMIENT

SEIPPINGPORT ATOMIC POWER STATION
16 HEAT LRCEANGE LEAT TEST DLCS 3330101

CORE I SEED 1

TABLE II

January 13 and 14, 1960

Leak Location Probe Test

Tube Lips Ground

sow

Tube

Leakage

Location

$\begin{array}{ll}2 & 9 * \\ 3 & 21 \\ 6 & 26 \\ 8 & 26\end{array}$

No leakage

$0 \mathrm{ml}$ in $32 \mathrm{~min}$.

No leakage

$46 \mathrm{ml}$. In $10 \mathrm{~min}$.

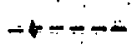

$--\infty-\infty$

0 to $6^{\prime \prime}$ from tube inlet

* Tube was blown twice with air after reducing secondary pressure to zero. Hith secondary pressure at 75 psig, sti11 no leakage detected. 
DUQUESNE LIGIT :COMPANT

POWER STATIONS DEPARTMENT

SHIPPINGPORT ATOMIC POWER STATION
15 HRAT ERGMANGE TMT TEST

DICS 3330101

CORE I SETH 1

\section{TABLE III}

Tube Inside Dimeter (1nches) by Boregage Test

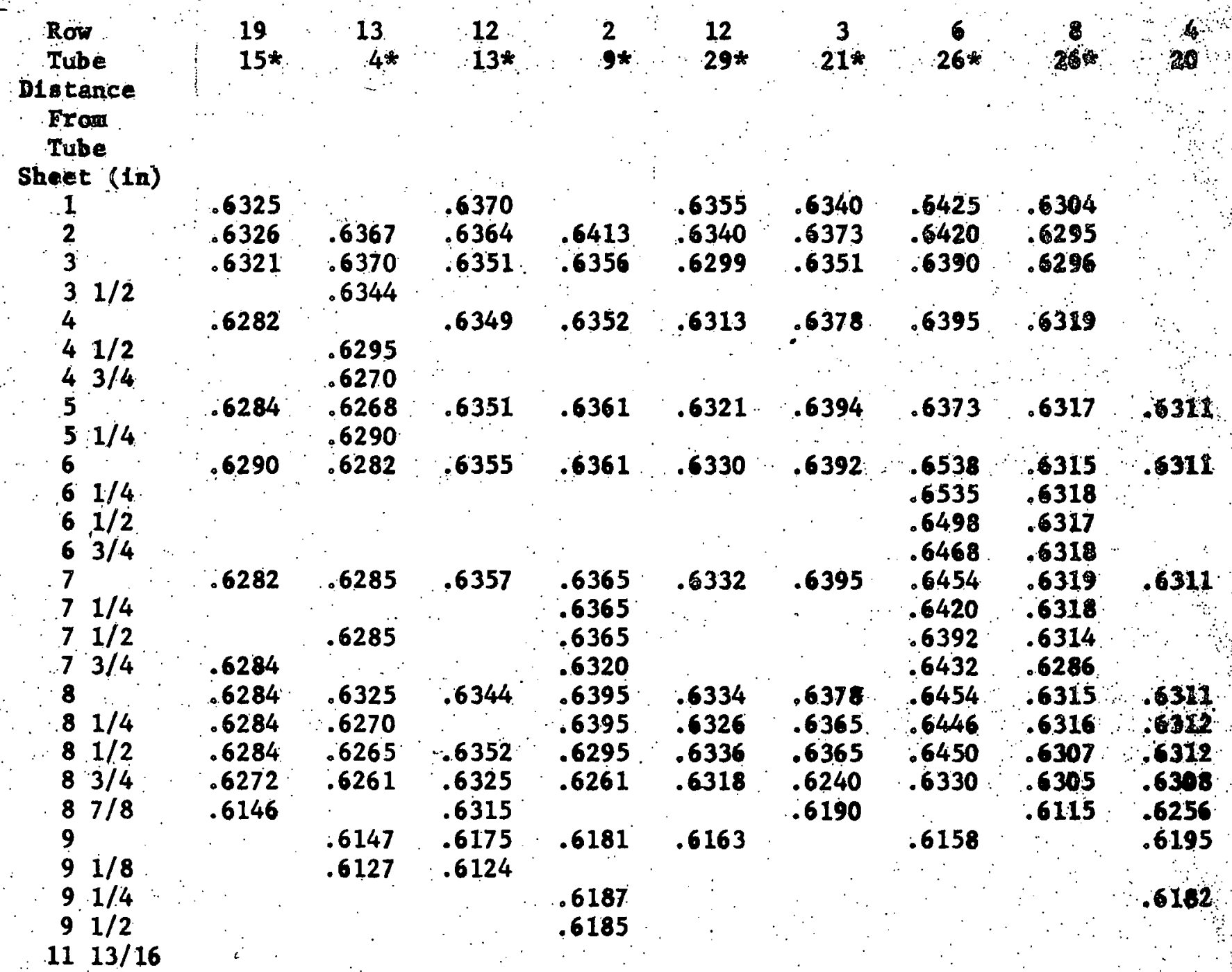

* Leaking tubes per alr pressurization test

(1) 11 measurements taken at tube inlet 
DUQUESNE LIGHT COMPANY

POWER .STATIONS DEPARTMENT

SHIPPINGPORT ATOMIC POWER STATION
18 ERAT EXCEARG TEAR TEST DLCS 3330101

CORE I SEED 1

TABLE III (cont'd)

Tube Ins1de Diameter (Inches) by Bozegage Test

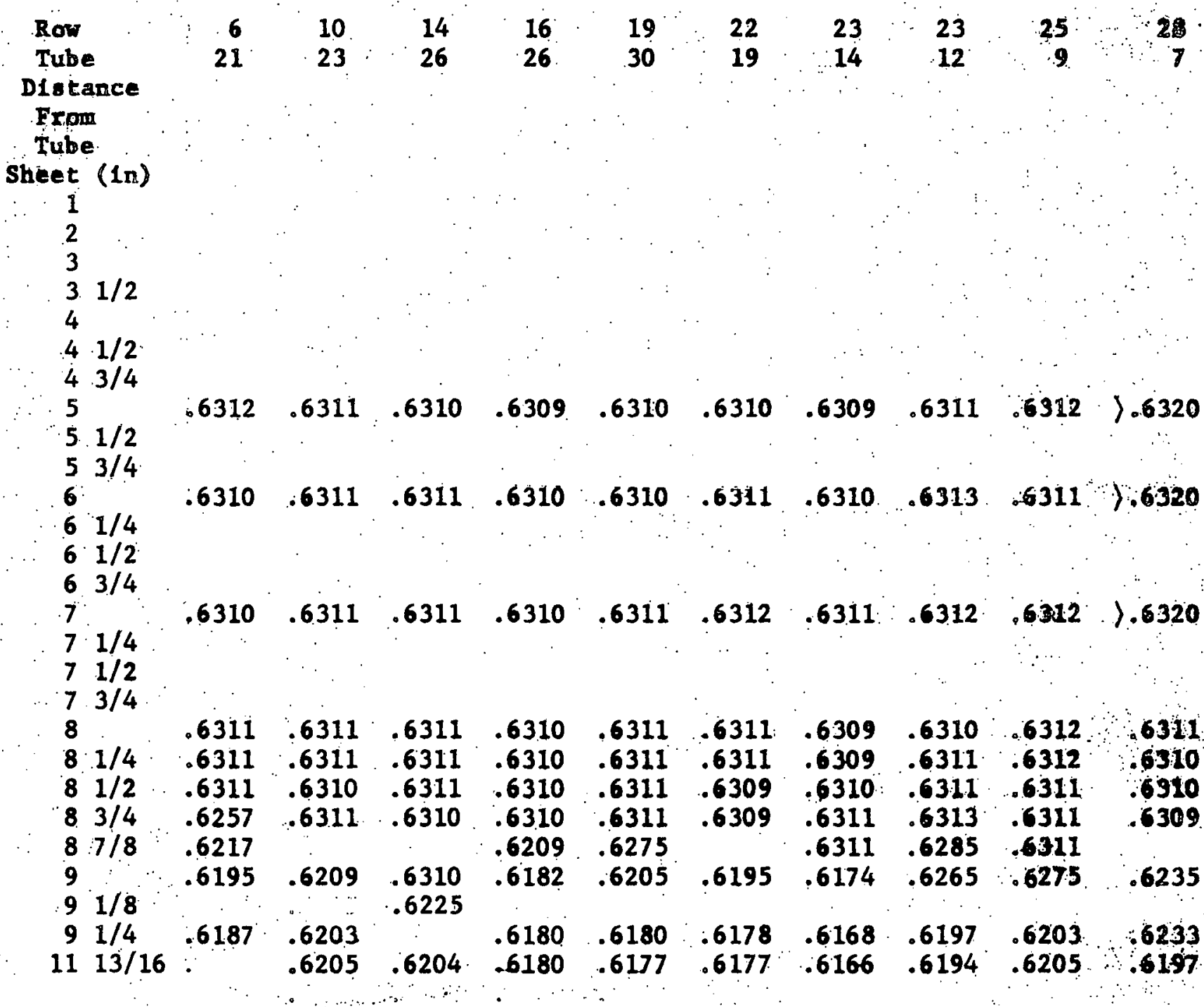

See Figure 5 
DUQUESNE LIGET COMPANY

POHER STATIONS DEPARTMENT

SHIPPINGPORT ATOMIC POWER STATION
18 HEAT ERCHANGE IEAT TET DLCS 3330101

CORE I SEED 1

TABLE IV

Tubes Tested by UItrasonic Method*

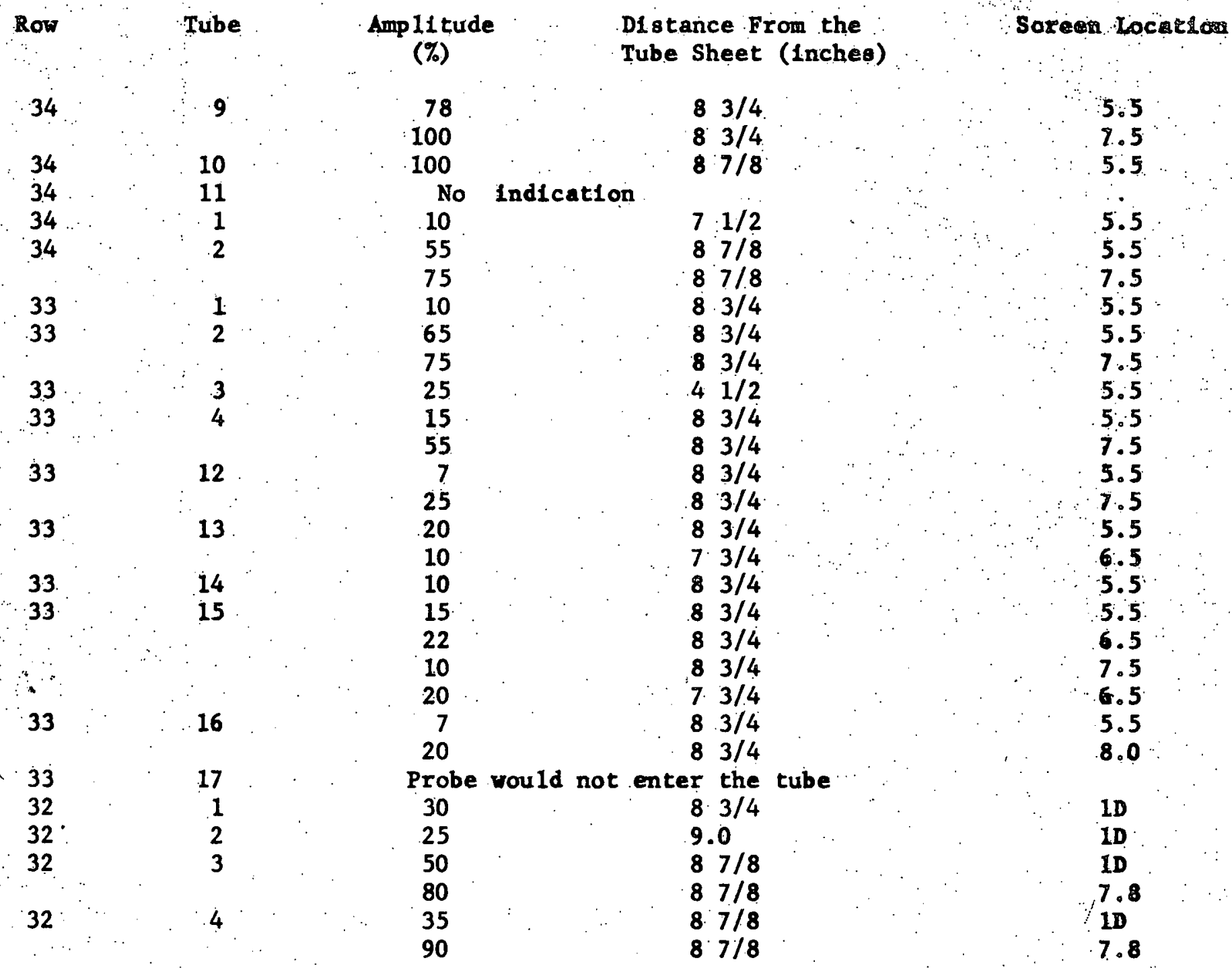

* All testing was done at the inlet side of the tubes 
DUQUESNE LIGHT COMPANY

POWER STATIONS DEPARTMENT

SHIPPINGPORT ATOMIC POWER STATION
1B BEAT BXCHANGE TRAX TBST DLCS 3330101

CORE I SEED 1

TABLE IV (cont! d)

Tubes Tested by U1trasonic Method

\section{Row}

32

.32

32

32

32

32

32

32

$31^{\circ}$

31

31

31

31

31

31

31

31

$-31$

31

31

31
Tube

titude

(\%)

\section{5}

6

8

9

13

14

15

16

15

14

1.3

12

11

10

9

8

7

6

5

4

3

20
45
20
80

10

15

10

15

10

$--$

20

--

15

14

20.

30

25

30

55

90

45

40

35

45

15 .
Probe would not enter the tube
Probe would not enter the tube

Back dam won't entar tube

Back dam won't enter tube

Back dam won' $t$ enter tube

Probe won't enter tube

Probe won't enter tube

Front dam won't enter tube

20 .
$87 / 8$

$87 / 8$

87.18

$87 / 8$

$87 / 8$

$87 / 8$

$87 / 8$

$8 \cdot 7 / 8$

$87 / 8$

$87 / 8$

$87 / 8$

$87 / 8$
Screan lacalon

1.D.

7.8

I.D.

7.8

1.0

7.8

10

7.8

1.D.

7.8

I.D.

7.8

1.D.

$7: 8$

1.D.

7.8

1.0.

78
1D

7,8

18 .

7.8

ID

7.8

18

7.8 
DUQUESNE LIGHT COMPANT

POWER STATIONS DEPARTMEINT

SHIPPINGPORT ATOMIC POWER STATION

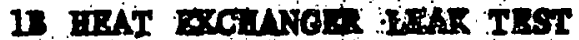
DLCS 3338101

CORE I SLT 1

TABLE IV (cont'd)

Tubes Tested By U1trasontc Method

Row

Tube

Amplitude

31

31

30

30

30

30

30

30

30

30

30

30

30

30

30
2

90

100

15

$1 \quad 15$

50

3.

1

2

3

30

.40

10

15

40

100

100

45

60

10

4

40

90

12

50

80

70

100

15

12

7

8

9

10

11

12

12. 30

50

10
(F)

Distance from the Tube Sheet (inches)

$87 / 8$

$87 / 8$

$83 / 4$

$87 / 8$

$87 / 8$

$87 / 8$

$87 / 8$

$87 / 8$

$87 / 8$

8. $7 / 8$

$87 / 8$

$87 / 8$

$8.7 / 8$

$87 / 8$

$87 / 8$

$87 / 8$

$87 / 8$

$8.7 / 8$

$87 / 8$

8. $7 / 8$

$87 / 8$

$87 / 8$

$8.7 / 8$

$87 / 8$

$87 / 8$

$8 \cdot 7 / 8$

$87 / 8$

Probe would not enter the tube

Probe yould not enter the tube

$87 / 8$

$8.7 / 8$

$87 / 8$

Front dain would not enter the tube

Rear dan would not enter the tube
Screen Location

17

7.8

0.8

1.D.

7.8

id

7.8

O.D.

10

7.8

10

7.8

110

7.8

0.0

17

78

OD

1D

7.8

10

7.8

iD

Q.D.

ID

7.8

OD

i1

$7: 8$

os 
DUQUESNE LIETT COMPANT

POWRR STATIONS DEPARTIRNT

SRIPPINGPORT ATOMIC POWER STATION

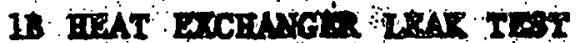
DLCS 3330101

CONE I SED I

TABLE IV (cont'd)

\section{Tubes Tested by U1trasonic Method}

Row

30

30

30

30

30

30

29

29

29.

29

29

29

27

27

27.

27
Arap li tude

13

14

15

16

17

18

7

9

11

13

14

15

17

18

8

10

13

30

60

30

60

40

45

25

30

28

$--$

50

90

90

100

15

25

60

90

12

18

20

40

25

40

20

35

25
Distance from the Tube Sheet (Inches)
Scrien Locs

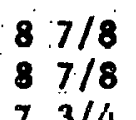

$73 / 4$

Rear dam would not enter the tube

Probe would not enter the tube

Probe would not enter the tube

Probe would not enter the tube

60
8. $7 / 8$

$87 / 8$

$87 / 8$

$87 / 8$

$8.7 / 8$

8. $3 / 4$

$87 / 8$

$8.7 / 8$

$87 / 8$

$87 / 8$

$87 / 8$

$8.7 / 8$

$87 / 8$

$87 / 8$

$87 / 8$

$87 / 8$

$8.7 / 8$

$87 / 8$

$87 / 8$

$87 / 8$

$87 / 8$

$87 / 8$

$87 / 8$

$87 / 8$

$87 / 8$

$87 / 8$
1D

7.8

0.D.

10

76

ob

os

OD

ob

ID

7.8

1D

7.8

ID

7.8

1D

OD

OD 
DUQUESNE LIGIT COMPANT

POWER STATIONS DEPARTILNT

SHIPPINGPORT ATOMIC POWER STATION

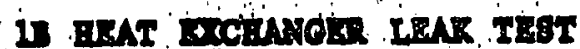
DLCs 3330101

CORE I SEED 1

TABLE IV (cont'd)

Tubes Teeted by U1traconlc Method

Row Tube

Aplitude

Distance fros the

Tube Sheet (Inches)

Scroen Localde

27

15

40

$8.7 / 8$

$87 / 8$

$8 \cdot 7 / 8$

$87 / 8$

$8.7 / 8$

$71 / 2$

21

13

$87 / 8$

(8. $7 / 8$

$87 / 8$

$87 / 8$

$87 / 8$

8. $7 / 8$

14

15

30

15

$9 \quad$ No Indication

2
6

$8 \quad 26$

12

13

35

10

$87 / 8$

ii

7.8

OD

10

$7: 8$

ID

7.8

ob

10

7.8

10

7.8

$\begin{array}{ll} & 10 \\ 5 & 1 / 2\end{array}$

OD

No Indication

10

10

10

$13 \div 4$

25

20

13

4*

60

15

11

13

25

20

14

20

15

$73 / 4$

1D

$73 / 4$

08

$89 / 8$

ID

1D

1D

10

1D

ID

1D

OD

$73 / 4$

$83 / 4$

$73 / 4$

$11 \quad \therefore 14$

11 13*

11

13*

Prob

20

5

10

15

the tube

ID

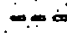

ID

10.

$7.3 / 4$

10

$7 \cdot 3 / 4$

1D

OD

$\star$ Recheck data 
DUQUESAL LIGAT COMPANT

POWLR STATIONS: DEPARTMLATI

SHIPPINGPORT ATOMIC POHL STATION

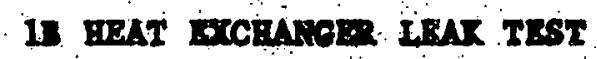
Drcs 3330101

CORE I SEED I

TABLE IV (cont' d)

Tubes Tested by UItrasonic Method

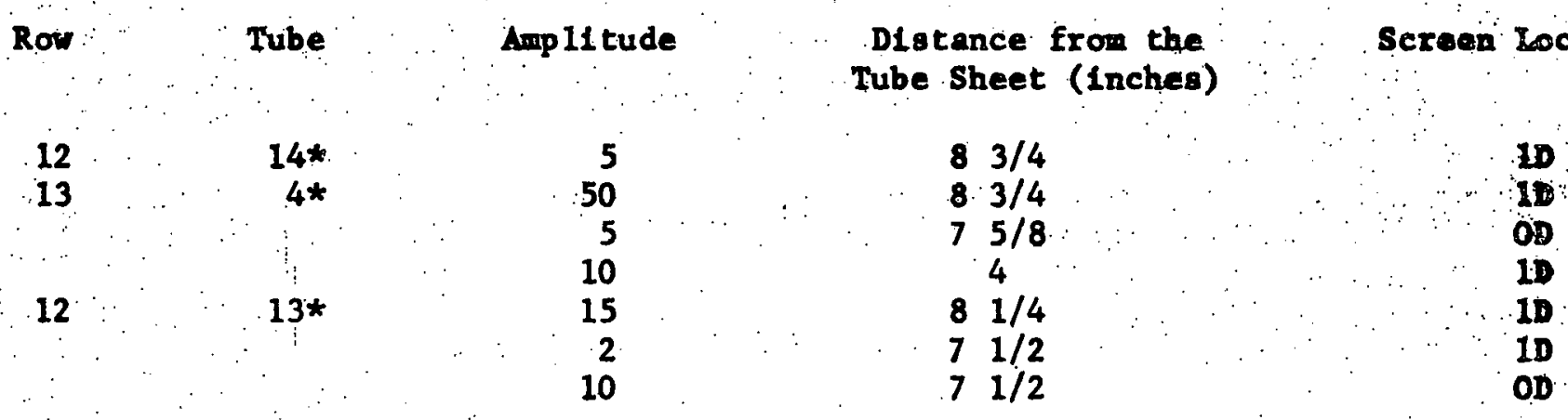

See Figure 17

* Recheck data 
DUQUESHE LIET COAPAII

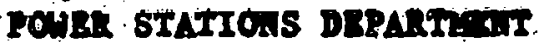

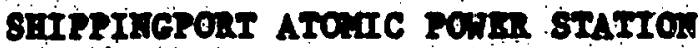

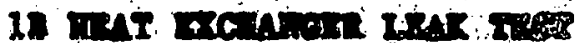
Dios 3330101

$\cos I$ I ssit i

TaSTS $\nabla$

I1In Badre Readings (Roentren)t

\begin{tabular}{|c|c|c|c|c|c|c|c|c|}
\hline \multicolumn{3}{|c|}{$\begin{array}{l}\text { Iiln Location } \\
2^{\text {II }} \text { Iron Tube Sheet }\end{array}$} & \multirow{2}{*}{$\frac{5 / 16 \text { Inch }}{\text { Pleotic }}$} & \multicolumn{2}{|c|}{ 1/6 Inch. } & I0 & $20 \mathrm{mi}$ & Betur- \\
\hline 20 & Tube & Position & & $\mathbf{P I}$ & Eic & Shielding & adal & Beta \\
\hline 7 & 22 & 7 o'clock & 3.63 & 3.94 & 4.05 & 4.90 & 4.06 & 7.8 \\
\hline 26 & 3 & 2 o'clock & 4.24 & 3.86 & 3.67 & 4.49 & 3.17 & 4.7 \\
\hline 21 & 16. & Hidpoint & 2.83 & 3.24 & 3.20 & 3.60 & 2.94 & 4.5 \\
\hline
\end{tabular}

\begin{tabular}{|c|c|c|c|c|c|c|c|c|}
\hline 611 & $\begin{array}{l}\text { Etin I } \\
\text { Eron. I }\end{array}$ & $\begin{array}{l}\text { ention } \\
\text { be Sheet }\end{array}$ & $5 / 16$ Inch & $1 / 6$ & Inch & $10^{\circ}$ & 2041 & Beta-orasen \\
\hline Rew & Tube & Los1t10n & Mastic & 2128 & Exc & strelche & Conato & Late \\
\hline 7 & $22^{\circ}$ & -7 o'clock & 2.65 & 2.94 & 2.98 & 3.60 & 211 & $1: 4$ \\
\hline 26 & 3 & $20^{\prime} \mathrm{clock}$ & 2.58 & 3.88 & 3.42 & 3.17 & 2.54 & 4,1 \\
\hline 21 & 16 & Midpoint & 2.03 & 2.30 & 2.08 & 2.01 & 1.75 & 6.7 \\
\hline
\end{tabular}

* Bxposure IIne One Hour

Leadings can be expresised to $\mathrm{h} / \mathrm{Hr}$. 
DUQUESSNE IRGET COMPANT

POWER STATIONS DEPARTMENT

SHIPPINGPORT ATOMIC POWER STATION

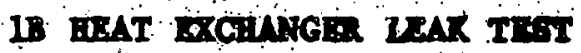

Dics 3330101

CORE I SLET 1

\section{Log of Events}

February $3,1.958$

October 21 and 22 1959

October 25, 1959

to

November 14,1959

January 13 and 14 1960

Jenuary 29, 1960 to

Fobruary 12, 1960

March 20-28, 1960

March 24 and 25 1960
It was determined that a leak of about 35 gallons per tous at 2000 psi differential presaure existed froin the primary to the secondary side of the is heat exchanger. On the basid of ats pressurization tests and probolog tests; four tubes sere removed and a total of 17 tubes were plugged.

Selected tubes of the 18 heat exchanger were sifjected to row bolog tests.

All unplugged tubes were checked for leaks by pressuring the secondary ilde with 75 psig alr, Leakage was indlcated In 9 tubes and leak rates were obtalned.

of the 9 tubes indlcating leakage the ends of 4 tibes were ground to permit the entry of a leak location detector probe. Measurable leakage was found in only one tube. Ale pregeuro was applied on the primary side of the previous leaktiog rubes to repen the cracks.

Selected tubes vere tented by the boregage method to deterwas instde diameters.

Selected tubes including the 9 leakdng tubes vere ofvon dye penetrant test.

Selected tubes were teoted by the ultrasontc method. 
DUQUESNE IIGHT COMPANY

POWER STATIONS DEPARTMENT

SHIPPINGRORT ATOMIC POWER STATION
1B . HEAT - EXCHANGER LEAK TEST DLCS 3330101

CORE I SEED 1

TABLE :VI

1B. Heat Exchanger Leak Rates

Activity of Reactor Secondary Boiler :Hours at. 100\% Leak Rate

Date Coolant $(\mathrm{dpm} / \mathrm{ml})\left(\mathrm{x}_{10}{ }^{3}\right)$ : Water Activity dpm/ml Reactor Power $\mathrm{ml} / \mathrm{min}$

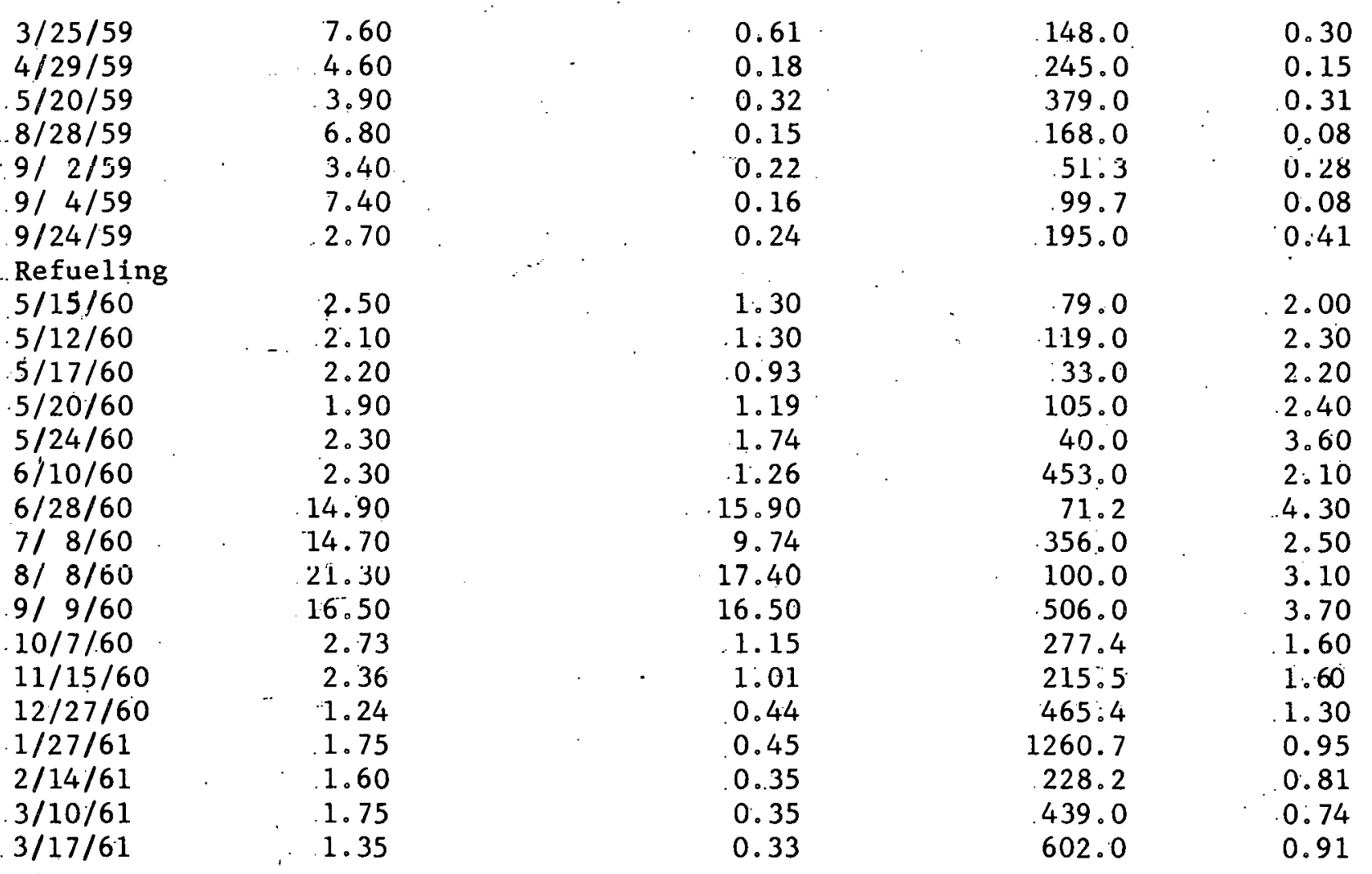


TEST RESULTS DECS 3330101

18 HEAT EXCHANGER LEAK TEST

CORE I SE 1

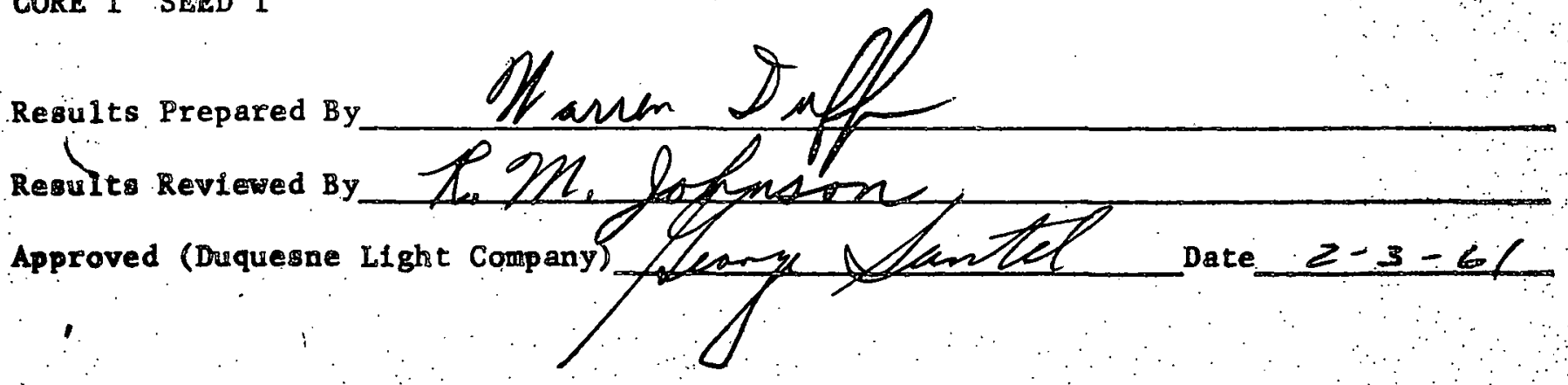

SECOND ISSUE

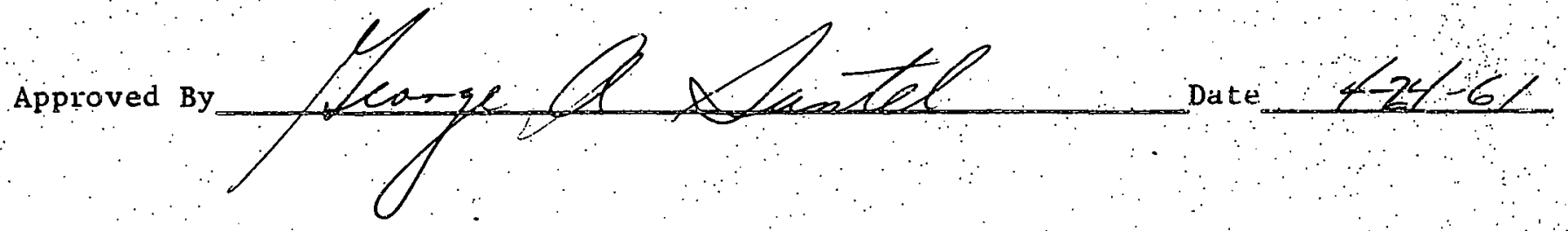

$-36-$

$666 \div 37$ 